\title{
Essays on international monetary institutions, monetary policy, and economic stability
}

\author{
Elham Mafi-Kreft \\ West Virginia University
}

Follow this and additional works at: https://researchrepository.wvu.edu/etd

\footnotetext{
Recommended Citation

Mafi-Kreft, Elham, "Essays on international monetary institutions, monetary policy, and economic stability" (2003). Graduate Theses, Dissertations, and Problem Reports. 1880.

https://researchrepository.wvu.edu/etd/1880

This Dissertation is protected by copyright and/or related rights. It has been brought to you by the The Research Repository @ WVU with permission from the rights-holder(s). You are free to use this Dissertation in any way that is permitted by the copyright and related rights legislation that applies to your use. For other uses you must obtain permission from the rights-holder(s) directly, unless additional rights are indicated by a Creative Commons license in the record and/ or on the work itself. This Dissertation has been accepted for inclusion in WVU Graduate Theses, Dissertations, and Problem Reports collection by an authorized administrator of The Research Repository @ WVU. For more information, please contact researchrepository@mail.wvu.edu.
} 


\title{
Essays On International Monetary Institutions, Monetary Policy, and Economic Stability
}

\author{
Elham Mafi-Kreft \\ Dissertation Submitted to the \\ College of Business and Economics at \\ West Virginia University \\ in partial fulfillment of the requirements for the degree of \\ Doctor of Philosophy \\ in \\ Economics
}

\author{
Russell Sobel, Ph.D., Chair \\ Ronald Balvers, Ph.D. \\ Subhayu Bandyopadhyay, Ph.D. \\ George Hammond, Ph.D. \\ William Trumbull, Ph.D. \\ Department of Economics
}

Morgantown, West Virginia

2003

Keywords: International Monetary Arrangements and Institutions, Monetary Policy, Stabilization Policy. 


\section{ABSTRACT \\ Essays On International Monetary Institutions, Monetary Policy, and Economic Stability}

\section{Elham Mafi-Kreft}

This dissertation is a collection of essays that focus on how the policy actions and design of monetary institutions affect various economic indicators, such as commodity prices, asset prices, and production. Chapter 1 of the dissertation discusses the role and design of monetary institutions. Chapter 2 outlines the process undertaken during the European economic and monetary unification with an emphasis on the European Central Bank (ECB). Chapter 3 empirically analyzes the effects that the ECB has had on the economic stability of its member countries. Specifically, substantial disagreement exists among economists about the degree to which central banks should pursue discretionary stabilization policy. The formation of the ECB provides a unique opportunity to test whether a shift to a less active central bank has resulted in more or less macroeconomic stability for these countries. Chapter 4 investigates whether barriers to currency competition placed on suppliers of money are associated with higher rates of inflation. First, I look at historical data on average annual inflation rates for nine OECD countries that experienced periods of free banking and compare them to their averages under central banking. Second, using a cross-section of OECD countries, I find that countries allowing citizens to legally hold foreign currency tend to have lower average rates of inflation. My results show that allowing competition among currency issuers heightens the incentives for monetary issuers to pursue lower inflation rates. Chapter 5 analyzes the monetary stability and overall economic performance of transition economies based on their chosen monetary regimes. The transition economies had several prominent monetary arrangements to choose from, such as sovereign central banks or currency boards. This chapter surveys the monetary institutions currently in place in several transition economies and compares them based on their ability to control inflation. Chapter 5 presents concluding remarks and summarizes the major findings of the research included in this dissertation. 


\section{ACKNOWLEDGMENTS}

My everlasting thanks belong to my companion in everything, Steven Kreft. He has been my closest partner in graduate school. We studied together, he read so many drafts of the dissertation, provided assistance, and was willing to discuss economics any time of day or night. Steven's intelligence, encouragement, unfailing enthusiasm and patience cheered me through the entire process.

To my advisor, Pr. Russell Sobel, I am greatly indebted for his guidance, support, and patience. Without Russ this work would neither have started, progressed, nor finished. He has truly been a source of encouragement, and a tremendous resource for all phases of this effort. His faith in my abilities never faded and he was always available, encouraging, and professional.

I would like to express my sincere appreciation to the members of my dissertation committee Pr. Ronald Balvers, Pr. Subhayu Bandyopadhyay, Pr. George Hammond and Pr. William Trumbull. They all have been great sources of help, and advice without which the completion of this work would not have been possible.

Finally, I cannot offer enough thanks to my parents who have always been my greatest source of strength and inspiration. The support I received from my parents and my brother has always been tremendous and I wish to express my endless thanks for their encouragement throughout. Papa, maman, and bambino, thank you for bringing me so much happiness over the years. 


\section{TABLE OF CONTENTS}

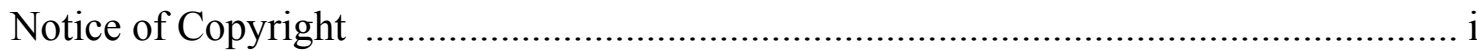

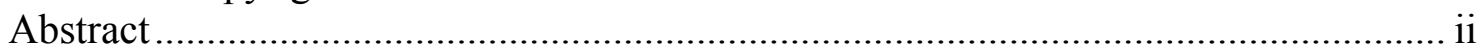

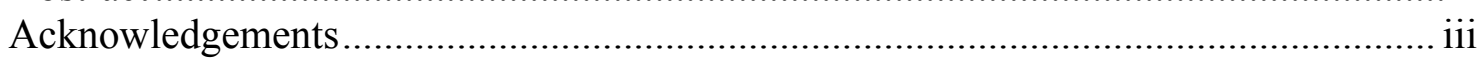

List of Tables and Figures........................................................................................ vi

Chapter 1:

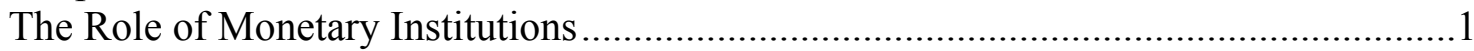

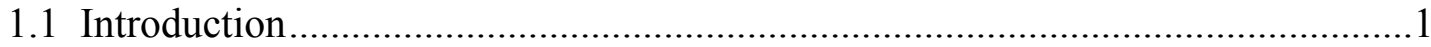

1.2 Dissertation Research Agenda …………….................................................

Chapter 2:

A New Monetary Institution: The European Central Bank ...........................................5

2.1 The European Central Bank...........................................................................

Chapter 3:

Does a Less Active Central Bank Lead to Greater Economic Stability?

Evidence from the European Monetary Union ................................................................9

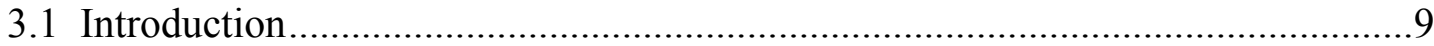

3.2 The EMU: Its Origins and the Previous Literature …………….......................12

3.3 A Monetarist Critique of the Previous Literature .................................................14

3.4 How Active Were the Old Central Banks? .......................................................16

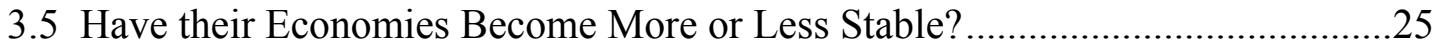

3.6 Conclusion ...............................................................................................

Chapter 4:

The Relationship Between Currency Competition and Inflation......................................35

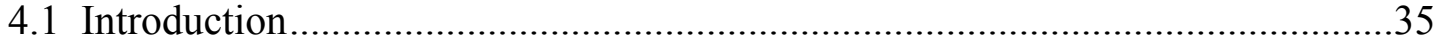

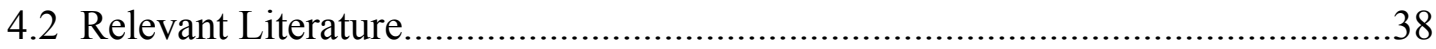

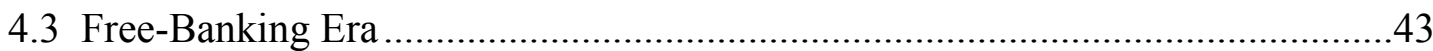

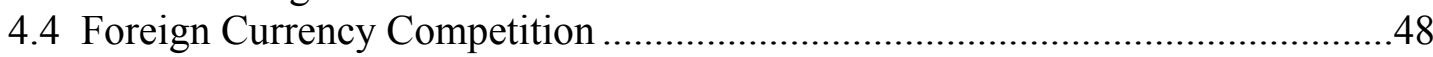

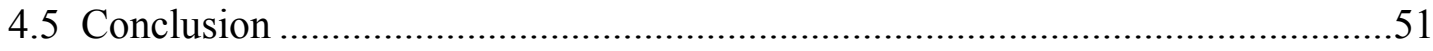

Chapter 5:

Importing Credible Monetary Policy:

A Way for Transition Economies to Fight Inflation.......................................................53

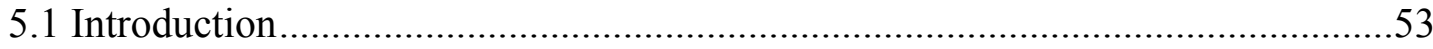

5.2 Central Banks Versus Currency Boards ..........................................................56

5.3 Economic Performances in Transition Economies ................................................59

5.4 Cross-National Analysis of the Determinants of Inflation

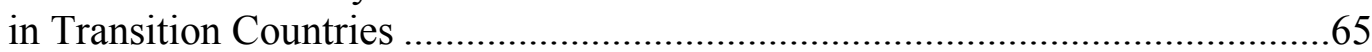

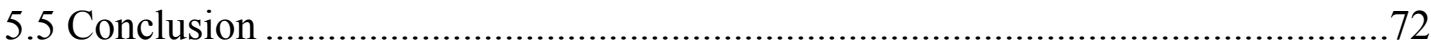


Chapter 6:

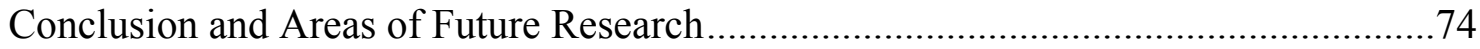

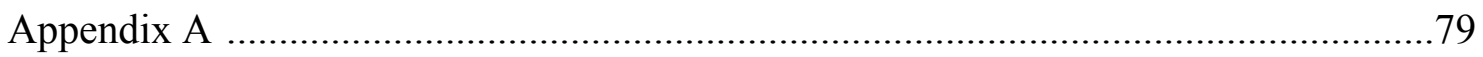

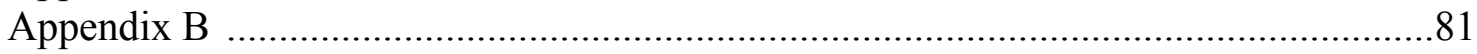

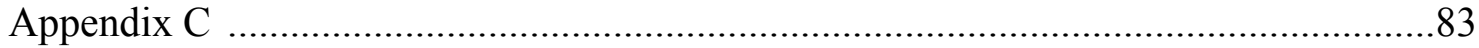

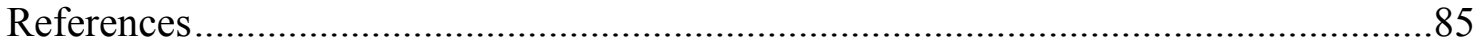




\section{LIST OF TABLES AND FIGURES}

\section{TABLES:}

Table 3.1 Measure of Central Bank Activism ...............................................................18

Table 3.2 Change in Economic Volatility Since Joining the EMU ...............................26

Table 4.1 Average Inflation During the Free-Banking Era and

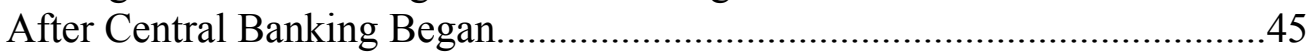

Table 4.2 Output Growth During the Free-Banking Era and After Central Banking Began.

Table 4.3 Determinants of the Average Inflation Rates for OECD Countries (1970-1999) ................................................................51

Table 5.1 Comparing Inflation Variances and Average Annual Inflation Rates for 26 Transition Countries (1995-2001) .......................................................62

Table 5.2 Determinants of the Inflation Rates

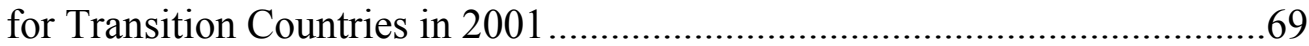

Table A.1Results of the Taylor Rule Regressions ........................................................79

Table B.1Inflation Variances During the Free-Banking Era and After Central Banking Began.

Table C.1Determinants of the Inflation Rates for Transition Countries in 2001 .84

\section{FIGURES:}

Figure 3.1 Comparison of Monetary Activism Among Central Banks ..........................23

Figure 4.1 Average Annual Inflation and Freedom to Use Alternative Currencies (1970-1999)...................................49

Figure 5.1 Average Annual Inflation and GDP Growth (1995-2001) .............................59 


\section{Chapter 1 \\ The Role of Monetary Institutions}

\subsection{Introduction}

The major goals of macroeconomic policy, both fiscal and monetary, are maintaining high levels of employment, achieving sustainable economic growth, and ensuring low and stable price levels. One question that has been widely debated in the literature is whether monetary policy can actually attain all three macroeconomic goals.

Nobel laureate Milton Friedman (1969) argues that employment cannot be stimulated in the long run by monetary policy and, that monetary policy cannot "fine tune" the economy. According to Friedman the best thing that monetary policy can do is "provide a stable ground for the economy" by keeping the rate of money growth in check. Issing (2000) summarizes the recent academic literature supporting Friedman's view that the role of monetary policy is to ensure price stability. This view is founded in the principle that high and variable inflation imposes a significant cost burden on society. For example, Barro (1996) and Carlson (1997) have shown that inflation has a negative impact on economic growth. Also, Altig (2002) points out that economic growth and price stability are not competing goals of the monetary authority. The author notes that the sustainability of economic prosperity is conditional on the emphasis that the monetary institution puts on maintaining price stability. In other words, price stability is needed for sustainable economic growth, which implies that the major goal of monetary policy should be price stability.

In order to effectively control prices, the monetary authority has to implement credible monetary policy. Therefore, an important mission of the monetary authority is to 
maintain credibility in the eyes of the public, or as stated by Issing (2000) the monetary authority must be able "...to have one's statements accepted as factual." Founded in the works of Kydland and Prescott (1977) and Barro and Gordon (1983), there has been a growing consensus that the most effective method for a central bank to garner credibility is to pre-commit to publicly announced monetary policy. The authors note that when central bankers are left to pursue their own objectives, they have a tendency to produce a high rate of inflation. More specifically, the inflationary bias has been shown to be overcome by gaining a good reputation and being credible. Likewise, the institutional structure of the monetary authority will shape the incentives faced by central bankers and give more or less credibility to monetary policy. For example, monetary authorities operating under a truly fixed-exchange-rate regime will have less discretionary powers in implementing their policies, which will ultimately give them more credibility. Also, Friedman (1960), in his Program for Monetary Stability, advocates a constant growth rate of the money supply in order to discipline the discretionary incentives of central bankers.

Building of the existing literature, Rogoff (1985) states that a credible reputation is best obtained by delegating monetary policy to a "conservative" central banker, where conservative implies that the central banker places more weight on inflation relative to output. Conservative also implies that the central banker is sheltered from political influences on targeting output growth. Cukierman (1992), Alesina and Summers (1993) empirically show that central bankers that face greater political pressures enact policies that produce higher levels of inflation, and therefore, lose credibility.

A movement towards more credible monetary regimes has characterized the end of the twentieth-century. For example, a new institution has been constructed in Europe 
that conducts a single monetary policy and is designed to be the most independent, and thus credible, monetary institution in place today. Also, many countries have decided to strengthen their commitment to price stability by "importing" credibility into their monetary policy through replacing their money with a strong currency, either Dollar or Euro. However, some countries have chosen to keep the sovereignty of their monetary policy and institutions.

\subsection{Dissertation Research Agenda}

There are three research chapters included in this dissertation that will present the outcomes of different institution and their policy actions. Chapter 2 will chronicle the events that led to the formation of the European Central Bank (ECB). The chapter will also elaborate on the process that is undertaken in forming the ECB's monetary policy, specifically highlighting the voting process, policy commitments, and level of independence.

Chapter 3 will use the formation of the ECB, and its single monetary policy, to test the effects that different monetary institutions have on economic stability. More specifically, when each country joined the EMU, it gave up its powers to use discretionary monetary policy. The ECB, in turn, targets economic stability for all of its member countries with, what will be shown to be a less active common monetary policy. The transition from a discretionary monetary authority, to a less active one, will be shown to produce greater economic stability for the member countries.

Chapter 4 will test if currency competition will place disciplinary pressures on central bankers to provide a credible money supply. Specifically, two different monetary 
institutions will be compared, free banking and central banking, to see if the level of currency competition leads to a more sound money supply. Also, the level of foreign currency competition faced by domestic currency providers will be analyzed for its effects on the soundness of the domestic currency. Results show that currency competition is an effective incentive for currency providers to keep inflation low, in other words discipline the monetary authorities and provide a credible currency.

Chapter 5 will analyze how the monetary institutions in transition economies influence their economic performance; specifically, analyzing inflation and economic growth. Within the existing transition economies, there have been various monetary institutions chosen to direct monetary policy. For example, some transition countries have enacted either independent central banks or currency boards. Also some transition economies have chosen to target admission into the European Union (EU) by constraining their monetary authority towards meeting EU guidelines. Results show that those countries adopting a currency board experience more stable and lower general price level. Also, countries targeting admission into the EU regardless of their monetary institution, experience lower price level. 


\section{Chapter 2 \\ A New Monetary Institution: The European Central Bank}

\subsection{The European Central Bank}

After World War II, in an attempt to prevent any other devastating military confrontations between European countries, Winston Churchill called for a United States of Europe. Churchill believed that European economic integration would help to maintain peace in the continent. Following Churchill's idea, six countries: Belgium, France, Italy, Luxembourg, the Netherlands, and West Germany established the European Economic Community in 1957 . Their goal was to eliminate trade barriers among member states and create a large common market for goods, services, labor, and capital. Together, with their economic integration, the member countries had the ultimate objective to strengthen Europe's monetary system by achieving a total monetary unification.

Many attempts were made to establish exchange rate stability between the member states, and a final effort led to the creation of the European Monetary System in 1979. The European Monetary System was designed to provide a zone of currency stability favorable to the creation of a monetary union. In 1992, the ratification of the Maastricht Treaty expressed the serious commitment of the European Community to create a common currency and establish a common central bank that would be in charge of a single monetary policy.

Following the Maastricht treaty, the European Monetary Institute was established in 1994. The Institute's role was to strengthen cooperation between the central banks of the European Union, harmonize the institutional arrangements, reinforce their 
independence, and monitor the harmonization of the economies of the member nations. ${ }^{1}$ The Eurosystem, including the European System of Central Banks and the European Central Bank (ECB), formally replaced the Monetary Institute in January 1999. From January 1999, the Eurosystem became solely responsible for conducting monetary policy in the European Monetary Union member states. ${ }^{2}$

The Governing Council formulates the Euroland monetary policy. The Governing Council consists of the governors of the national central banks and the Executive Board, which includes the president, vice-president, and four directors of the ECB. The Governing Council meets every two weeks in the ECB's office at Frankfurt to formulate the Euroland monetary policy, and then, the Executive Board, which gives specific instruction to each individual national central bank, implements the policy. Therefore, the old national central banks are only responsible for executing the monetary policy handed down by the ECB. Also, the old national central banks are responsible for supervising and regulating the banking industries in their respective countries.

The Governing Council uses majority voting to decide what monetary policy to implement. All voters are required to implement a monetary policy that promotes the

\footnotetext{
${ }^{1}$ The European Community became know as the European Union in 1993. Currently, the European Union includes: Austria, Belgium, Denmark, Finland, France, Germany, Greece, Ireland, Italy, Luxembourg, the Netherlands, Portugal, Spain, Sweden, and the United Kingdom. However, in April 2003, leaders of the European Union met in Athens, and officially invited ten candidates to join the European Union in May 2004. The ten candidates included Latvia, Lithuania, Estonia, Poland, Hungary, the Czech Republic, Slovakia, Slovenia and the Mediterranean islands of Cyprus and Malta. All future members of the European Union will join the European Monetary Union and adopt the Euro as their currency by maintaining established convergence criteria.

${ }^{2}$ The European Monetary Union member states are Austria, Belgium, Finland, France, Germany, Greece, Ireland, Italy, Luxembourg, the Netherlands, Portugal, and Spain. The area formed by the EMU member states is referred to as Euroland.
} 
interest of Euroland as a whole. However, it is conceivable that the governors of the national central banks are more likely to vote according to their respective national interests. In contrast, the executive board will more likely base its monetary decisions on Euroland aggregates.

The ECB is an institution that has been designed to conduct a single monetary policy that is different from what most of the old national central banks have conducted in the past. ${ }^{3}$ In particular, the ECB has been shaped after the Bundesbank, one of the most price-stability-oriented central banks in the world. In other words, at a time when most national central banks were pursuing price stabilization, as well as, output stabilization, the Bundesbank considered price stabilization as its principal objective. The ECB has announced that it will achieve price stability by targeting a rate of inflation below $2 \%$ per year for the Euroland. Also, as a reliable indicator of current and future price stability the growth rate of the money aggregate M3 is closely monitored at $4.5 \%$. Clearly, the ECB adheres to Friedman's philosophy of pre-commitments and clearly announced monetary policies to produce credible and effective monetary policy.

The ECB has been characterized as the most politically independent central bank. This political independence is strengthened by the fact that only a unanimous decision by all the EU-members could change the institution of the ECB. The ECB is not allowed to lend money to any government of Euroland, and is not required to report to any member countries. To account for its policy actions the ECB will publish quarterly reports on the

\footnotetext{
${ }^{3}$ As De Grauwe (2000) stated, the ECB is part of the Eurosystem but is commonly used by economists as a synonym for the Eurosystem. Therefore, the term ECB will refer to the Eurosystem for the remainder of this dissertation.
} 
bank's activities, and will present an annual report of its monetary policy to the European Parliament. In an attempt to increase the transparency of the ECB's monetary policy, the ECB president regularly publishes the ECB's economic forecasts, which characterize the economic prospects of Euroland.

The next chapter will look closer at the European Central Bank institution and empirically test whether the switch to this new monetary institution has helped stabilize the economies of the EMU member states. 


\section{Chapter 3 \\ Does a Less Active Central Bank Lead to Greater Economic Stability? Evidence from the European Monetary Union*"}

\subsection{Introduction}

On January 1, 1999 eleven European countries gave up the independence of their monetary policy by joining the European Monetary Union (EMU). Since that time, these countries have shared a common currency, the Euro, and more importantly are all now under the direction of a common European Central Bank (ECB) that controls monetary policy for the entire Euro area. In accordance with Article 105(1) of the Maastricht Treaty, the primary objective of the ECB is to maintain price stability. The institutional designs of the ECB as well as their stated primary objective lead most economists to believe that the new ECB is a relatively inactive central bank in the pursuit of short-run macroeconomic stabilization. Thus most, if not all, of the countries in the EMU are now under a central bank that is much less active than was their previous national central bank. In this chapter, I examine whether this shift in the activism of the monetary regime has resulted in more or less macroeconomic stability for these countries.

Even prior to the official starting date for the EMU, a substantial academic literature speculated on how the move toward a common central bank would affect the macroeconomic stability of these countries. This literature has generally concluded that the movement toward a common central bank would make these economies more unstable because of the inability of a common central bank to tailor monetary policy to the needs of each country. As each country experiences country-specific shocks, the ECB

\footnotetext{
* The ideas in this chapter are developed in Mafi Elham and Sobel Russell "Does a Less Active Central Lead to Greater Economic Stability? Evidence from the European Monetary Union." WVU Working Paper 02.02 .
} 
will not be able to counter these shocks as well as a system of autonomous central banks. Thus, this previous academic literature has concluded on theoretical grounds that the EMU-member countries will suffer wider swings in real economic activity after the move to a common central bank. ${ }^{4}$

A monetarist critique of this position has yet to appear in the literature, however. The monetarists have long argued that monetary policy is the main source of economic instability, even when the policy is well-intentioned. Brunner (1985) states the monetarist position concisely in his quote (p.12): "Discretionary management ultimately fails to deliver, even with the best intentions, on its promise." The monetarists believe that problems with lags and proper timing result in policy errors that induce less, rather than more, economic stability. If this position is correct, it suggests that having a common central bank that is unable to optimally respond to individual country-specific shocks could actually result in greater economic stability in the EMU member countries. In other words, a common policy that is less responsive to country-specific shocks will result in greater stability because there will be fewer macroeconomic swings induced by monetary policy errors. However, for some countries that used to have a very inactive national central bank (such as Germany's Bundesbank), the new ECB might actually be more active than the old national central bank. In this case, the monetarist position would argue that these economies would become more unstable after moving under a more active ECB.

Three decades ago, a substantial academic debate raged about the relative effectiveness of fiscal and monetary policy at providing economic stabilization. Now, a

\footnotetext{
${ }^{4}$ For a discussion on the possible effects of a common central bank refer to Feldstein (1997, 2000), De Grauwe (2000), Salvatore (2002) and Martin-Das (2002).
} 
consensus appears to have emerged that fiscal policy is generally less effective than monetary policy to promote short-run economic stability. ${ }^{5}$ In this modern view, fiscal policy should primarily be concerned with promoting long-run economic growth through maintaining reasonably low marginal tax rates, constraining deficit finance, and removing regulations and taxes that interfere with domestic or international economic transactions. Monetary policy, on the other hand, should be the method with which countries conduct economic stabilization. The main debate that remains is whether well-intentioned monetary activism is actually effective at promoting stability, a debate that is more important today than ever before with fiscal policy no longer being considered an effective stabilization tool.

The formation of the EMU provides a unique opportunity to see how a change in the activism of monetary policy affects the economic stability of a country. The evidence from this European monetary transformation will clearly help to resolve the substantial disagreement among economists on the issue of whether monetary activism provides more or less macroeconomic stability. If well-intentioned activist monetary policy cannot promote economic stability, it would suggest that the main focus of central banks should be on long-run price stability, rather than on short-run macroeconomic stabilization.

This chapter proceeds by first reviewing some of the previous literature on the EMU and presenting a monetarist critique of this literature. I then proceed to measure how active each country's national central bank was prior to the formation of the EMU and compare this with how active the new ECB has been since it was created. Finally, I examine which countries have seen the greatest increases (or decreases) in economic

\footnotetext{
${ }^{5}$ Rasche and Thornton (2001) present arguments on the ineffectiveness of fiscal policy in achieving shortrun stability.
} 
stability since joining the EMU, and attempt to find a correlation between the change in the activism of monetary policy and the change in economic stability.

\subsection{The EMU: Its Origins and the Previous Literature}

The Maastricht Treaty signed in February 7, 1992 by the fifteen members of the European Union called for the creation of a new ECB by January 1, 1999. The ECB would be assigned the task of conducting the single monetary policy for the eleven EMU members. ${ }^{6}$ The statute of the ECB (Protocol, Article 2) states that the primary and overriding goal of the European monetary authority is to "maintain price stability."7 Following almost perfectly the monetarist view, constant growth rate rules for the money supply have a prominent role in the statute of the ECB (the Euro area M3 money supply has a 4.5 percent growth rate reference value, for example). Undeniably, the ECB is based on a more monetarist framework similar to that of the old German Bundesbank, where the weight that monetary policy puts on long-run price stability significantly exceeds the weight put on maintaining short-run economic stability.

In his address to the Federal Reserve Bank of Kansas in 1999, the president of the ECB, Wim Duisenberg, reemphasized the commitment to price stability of the ECB. Duisenberg stated that monetary policy should never be reoriented away from its primary objective of maintaining price stability. He continued by emphasizing that low and

\footnotetext{
${ }^{6}$ Austria, Belgium, Finland, France, Germany, Ireland, Italy, Luxembourg, The Netherlands, Spain and Portugal satisfied the economic criteria imposed by the Maastricht Treaty and formed the EMU on January 1, 1999. Greece met the criteria to join the EMU in January 1, 2001. The United Kingdom and Denmark opted out of the EMU because of their concern about the loss of national sovereignty.

${ }^{7}$ The statute defined price stability as maintaining the yearly increase in the Harmonized Index of Consumer Price to be less than $2 \%$ for the Euro area.
} 
predictable inflation is necessary for maintaining sustainable output growth and high levels of employment. Duisenberg made it clear that the ECB believes that even moderately high rates of inflation are harmful to economic growth. ${ }^{8}$ Furthermore, the fact that the ECB is following this more nonactivist framework can be found by looking at its actions in 2001 when the global risk of a recession was apparent. That year, while the U.S. Fed cut interest rates eleven times and the Bank of England cut interest rates seven times, the ECB cut interest rates only four times despite worldwide pressures to do more.

Even prior to the ECB formally coming into existence in 1999, an academic literature began to emerge speculating on how the move toward a common central bank would affect the economic stability of the European member countries. The consensus that emerged from this literature contained little hope that there would be an increase in economic stability. Eichengreen (1992), Bayoumi and Eichengreen (1993, 1997), for example, pointed out that the members were not forming an optimum currency area as was defined by Mundell (1961). An optimum currency area consists of a group of countries that share similar economic shocks and between which labor and capital can flow freely. Because of the dissimilarity of the shocks historically experienced by the EMU member nations, there are likely to be situations in the future where the optimal monetary policy will differ across these countries. A common central bank will be unable to tailor monetary policy to suit the needs of each nation simultaneously, however. Because the new ECB will be unable to optimally respond to these asymmetric (countryspecific) shocks, the economies of these nations will become less stable as a result.

\footnotetext{
${ }^{8}$ This argument is shared by Barro (1996) who found a negative relation between inflation and economic performance in 100 countries from 1960-1990.
} 
Similarly, De Grauwe (2000) shows that for asymmetric shocks the ECB would stabilize too little from the point of view of what would be optimal for the individual member states because it will be reacting to an average across all countries. Stevens (1999) claims that the inability of the ECB to respond to individual country needs could eventually lead to members withdrawing from the EMU. Likewise, Salvatore (2002) claims that when a country is hit by an asymmetric shock, the country will ultimately have to wait for the economy to self-correct. Salvatore believes that the self-correcting process may be lengthy, and no government could politically afford to tolerate such a drawn-out process. Salvatore provides evidence that Italy and Spain are the EMU members that will most often face asymmetric shocks, and therefore, will face the highest cost of the shared monetary policy.

\subsection{A Monetarist Critique of the Previous Literature}

The previous literature on the likely effects of moving toward a common ECB is rooted in a fundamentally activist theoretical framework. However, a substantial disagreement exists among macroeconomists about the validity of this position. In particular, monetarists believe that there are problems in monetary policy implementation that may significantly reduce the potential for active monetary policy to stabilize an economy.

The monetarist view can be summarized by a belief that lags in the implementation of monetary policy create a situation in which it is generally impossible to properly time monetary stimulus and contraction. Thus, the use of activist stabilization policy will frequently result in errors that result in wider business cycle swings than would be present if the central bank simply did not respond to economic shocks. The 
main conclusion of the literature in this area, typified by Friedman $(1961,1968)$, Brainard (1967), Phelps (1968), Brunner (1985), Meltzler (1987) and Orphanides (1998, 2000, 2002), is that monetary policy should primarily be concerned with long-run price stability, rather than short-run stabilization and that the economy will be more stable as a result. $^{9}$

The monetarist view would suggest a much different picture about the likely effects of moving to a common central bank than has been painted by the previous literature. If, as the monetarists believe, well-intentioned monetary activism actually results in less economic stability, then the inability of a common central bank to respond to all of these asymmetric shocks will actually result in greater economic stability. In addition, the countries that will find the largest increases in economic stability are precisely the ones that used to have the most active central banks. On the other hand, for some countries that used to have very inactive national central banks, such as Germany, it is possible that the new ECB is actually more active than the old national central bank. If this is true, it is possible that they will see less economic stability after moving under a more active central bank.

Thus, there are two competing models that produce totally different predictions for how the economic stability of each country will change after the formation of the EMU. The activist model that has served as the foundation for the previous literature

\footnotetext{
${ }^{9}$ Ellison and Valla (2000) show that strategic interactions between central banks and private agents create additional motivation for less activism in monetary policy. In particular, activism by central banks will lead to more fluctuations in inflation expectation by private agents, which may eventually translate into more volatile output and less social welfare. Furthermore, this theory apply that a central bank, which takes into account the fact that its actions affect learning, should choose to be less active than a central bank that ignores learning effects.
} 
predicts that a common central bank that is less active with respect to asymmetric shocks will result in less economic stability, while the monetarist model predicts just the opposite. The monetarist model predicts that the lack of response to these shocks should result in greater economic stability. Thus, by examining how the economic stability of these countries has changed since the move to a common central bank, and how this change is related to the activism of the old national central bank, it is possible to test the predictions of these competing schools of thought.

\subsection{How Active Were The Old Central Banks?}

In this section, data are presented on how active the central banks of Austria, Belgium, France, Germany, Italy, and Spain were prior the formation of the EMU.$^{10}$ Data are also presented on how active is the newly created European Central Bank.

Activism is traditionally defined as the degree to which central bank policy responds to short-run fluctuations in real economic activity. Thus, a good measure of monetary activism would include changes in monetary policy associated with changes in short-run economic conditions. In an attempt to obtain precise measures of monetary activism, I estimated a forward-looking Taylor rule model for each country to estimate the old national central banks' response to real economic conditions following the approach taken by Faust, Rogers, and Wright (2001). This type of policy reaction function assumes that the central banks have a targeted nominal interest rate, $\mathrm{r}_{\mathrm{t}}{ }^{*}$, that depends on the expected output gap, $E_{t}\left(y_{t}\right)$, and expected inflation, $E_{t}\left(\pi_{t+n}\right)$ following the equation:

\footnotetext{
${ }^{10}$ This is the set of countries for which consistent and reliable data were available.
} 


$$
r_{t}^{*}=\alpha+\beta E_{t}\left(\pi_{t+n}\right)+\gamma E_{t}\left(y_{t}\right)
$$

The model incorporates interest-rate smoothing such that:

$$
r_{t}=\rho r_{t-1}+(1-\rho) r_{t}^{*}+v_{t}
$$

Where $1 \geq \rho \geq 0$ and $v_{t}$ is a random shock to the interest rate that is assumed to be i.i.d.

Substitution produces the equation to be estimated

$$
\mathrm{r}_{\mathrm{t}}=\rho \mathrm{r}_{\mathrm{t}-1}+(1-\rho) \alpha+(1-\rho) \beta \pi_{\mathrm{t}+\mathrm{n}}+(1-\rho) \gamma \mathrm{y}_{\mathrm{t}}+\varepsilon_{\mathrm{t}}
$$

Where $\varepsilon_{\mathrm{t}}=\mathrm{v}_{\tau}+(1-\rho) \beta \mathrm{u}_{\mathrm{t}+\mathrm{n}}^{\pi}+(1-\rho) \gamma \mathrm{u}_{\mathrm{t}}^{\mathrm{y}}, \mathrm{u}_{\mathrm{t}+\mathrm{n}}^{\pi}=\pi_{\mathrm{t}+\mathrm{n}}-\mathrm{E}_{\mathrm{t}}\left(\pi_{\mathrm{t}+\mathrm{n}}\right)$, and $\mathrm{u}_{\mathrm{t}}^{\mathrm{y}}=\mathrm{y}_{\mathrm{t}}-\mathrm{E}_{\mathrm{t}}\left(\mathrm{y}_{\mathrm{t}}\right)$.

In the equation, $r_{t}$ is the nominal interest rate, $\pi_{t+n}$ is the targeted inflation rate (with $\mathrm{n}=12$ ) and $\mathrm{y}_{\mathrm{t}}$ is the output gap. The output gap is measured as the percent deviation of log-industrial production from its trend. ${ }^{11}$ The estimated parameters from each central bank's reaction function can be used to measure the degree to which they target long-run price stability versus smoothing short-run economic fluctuations. These are reflected in the estimates $\beta$ and $\gamma$ respectively. Thus, an obvious measure of central bank activism is the ratio $\gamma / \beta$. A higher magnitude of the ratio $\gamma / \beta$ shows that central bank policy was relatively more active in targeting the output gap, and thus exhibited a higher degree of monetary activism.

I estimate this Taylor rule model for each country using monthly data from January 1979 to December $1998 .^{12}$ Again following Faust, Rogers, and Wright (2001), I

\footnotetext{
${ }^{11}$ I measured the output gap by the percent deviation of the log-industrial production from a linear trend. The results using a linear trend are close to those using deviations from a quadratic trend.

${ }^{12}$ Clarida, Gali and Gertler $(1997,2000)$ advise the use of long time spans to improve the accuracy of the coefficient estimates. To see whether it significantly affected my results, the estimations were also run omitting the years 1990-1993, the period referred to as the hard Exchange Rate Mechanism. These years were omitted because Clarida, Gali and Gertler (1997) argued that the national central banks had lost all control of their monetary policy to the dominant Bundesbank during this period. Results after the omission
} 
used an instrumental variable approach. For instruments of the targeted inflation rate and the output gap, I used six lagged values of the interest rate, inflation, and the output gap. The resulting $\gamma / \beta$ ratios from our estimations are presented in the first column of Table 3.1 .

Table 3.1 - Measures of Central Bank Activism

\begin{tabular}{|c|c|c|c|c|c|c|c|}
\hline \multirow[t]{2}{*}{ Country } & \multirow{2}{*}{$\begin{array}{l}\text { Weight on } \\
\text { Output Gap } \\
\text { Relative to } \\
\text { Expected } \\
\text { Inflation }(\gamma / \beta)\end{array}$} & \multicolumn{2}{|c|}{$\begin{array}{c}\text { Standard Deviation } \\
\text { Of M2 Growth Rate } \\
\text { in Percent }\end{array}$} & \multicolumn{2}{|c|}{$\begin{array}{c}\text { Variance of } \\
\text { Nominal Short-Term } \\
\text { Interest Rate }\end{array}$} & \multicolumn{2}{|c|}{$\begin{array}{c}\text { Variance of } \\
\text { Real Short-Term } \\
\text { Interest Rate }\end{array}$} \\
\hline & & $\begin{array}{l}\text { Absolute } \\
\text { value }\end{array}$ & $\begin{array}{c}\text { Relative } \\
\text { Value }\end{array}$ & $\begin{array}{c}\text { Absolute } \\
\text { value }\end{array}$ & $\begin{array}{l}\text { Relative } \\
\text { Value }\end{array}$ & $\begin{array}{c}\text { Absolute } \\
\text { value }\end{array}$ & $\begin{array}{c}\text { Relative } \\
\text { Value }\end{array}$ \\
\hline \multicolumn{8}{|c|}{ Prior to formation of EMU (before January 1999) } \\
\hline Germany & 0.03 & $\begin{array}{c}0.54 \\
(0.62)\end{array}$ & $\begin{array}{c}0.55 \\
(0.61)\end{array}$ & $\begin{array}{c}4.3 \\
(5.3)\end{array}$ & $\begin{array}{l}10.3 \\
(9.5)\end{array}$ & $\begin{array}{c}1.0 \\
(2.6)\end{array}$ & $\begin{array}{c}3.6 \\
(6.5)\end{array}$ \\
\hline Austria & 0.09 & 0.48 & 0.48 & 5.4 & 8.5 & 2.6 & 6.1 \\
\hline Belgium & 0.14 & 0.48 & 0.58 & 5.1 & 9.1 & 3.1 & 9.3 \\
\hline Spain & 0.25 & 0.61 & 0.61 & 14.8 & 37.7 & 7.3 & 23.3 \\
\hline France & 0.35 & 0.85 & 0.75 & 6.8 & 10.2 & 4.1 & 13.8 \\
\hline Italy & 0.45 & 1.17 & 1.10 & 7.0 & 28.0 & 2.7 & 16.1 \\
\hline U.S. & 0.15 & 0.23 & & 3.3 & & 1.9 & \\
\hline \multicolumn{8}{|c|}{ After formation of EMU (since January 1999) } \\
\hline ECB & & 0.33 & 0.34 & \begin{tabular}{|l|l|}
0.8 \\
\end{tabular} & 3.5 & 0.1 & 1.1 \\
\hline U.S. & & 0.33 & & 1.6 & & 1.0 & \\
\hline
\end{tabular}

Notes: One of the largest shocks to hit Germany in the early 1990s was the reunification of Western and Eastern Germany. The monetary response of the Bundesbank during the reunification time period was extra-ordinary. I believe it distorts quite a bit the real measure for the Bundesbank's monetary policy especially in my measures of variance and standard deviation where outliers drive the results. The results in this table show both the data excluding the year of the German reunification and, the data with the full sample in parenthesis. The period pre-EMU for the estimations of the Taylor Rule covers the period 1979:01 to 1998:12. The period pre-EMU for the M2 and short-term real and nominal interest rates covers the period 1987:01 to 1998:12. The period post-EMU covers the period 1999:01 to 2001:12.

According to the ratios, the national central banks show two clear groupings with Italy, France, and Spain being the most active and Austria, Belgium, and Germany being the least active of the old national central banks prior to the formation of the EMU. ${ }^{13}$

showed an even clearer distinction between the two groupings of central banks than the ones presented in table 3.1. I estimated the Taylor rule using data from the International Financial Statistic CD-ROM.

${ }^{13}$ I present the individual estimates for $\gamma$ and $\beta$ in the appendix $\mathrm{A}$, but it is worthwhile to mention that Germany, Austria and Belgium had the lowest magnitude of the parameter $\gamma$ even without it being in ratio with $\beta$. In addition, only Germany, Austria, and Belgium had values of $\beta>1$ (implying that the central bank 
Measuring the activism of monetary policy is not an easy task, and there exists no consensus on how to empirically measure the size and direction of changes in monetary policy. Therefore, to check the robustness of my measure of central bank activism I follow the works of Sims (1972), and Grier $(1984,1989)$ that identify changes in monetary policy by measuring changes in the stock of money, defined as M1. ${ }^{14}$ More recently, alternatives to M1 have also been used. For example, Sims (1992), Bernanke, and Blinder (1992), Bernanke, and Mihov (1995), and Caporale and Grier (1998) use changes in the U.S. federal funds rate as their measure of monetary policy.

The debate over measures of monetary policy has centered on the choice of monetary aggregates versus interest rates. While monetary aggregates are endogenous and not under direct control of central banks, monetary aggregates are highly correlated with movements in inflation. ${ }^{15}$ Therefore, movements in monetary aggregates reflect the policy actions of the central banks. Table 3.1 presents several measures of monetary activism for each country based on M2, as well as real and nominal short-term money market interest rates.

For easy comparison to the more sophisticated measure of monetary activism the second sets of columns of Table 3.1 report data on the volatility of M2 money growth for the period 1987:01 to $1998: 12{ }^{16}$ The larger the number, the more active was the central

increased the nominal interest rate in response to inflationary pressures enough so that the real interest would rise) and therefore actively fought inflation, again showing their more monetarist stance.

${ }^{14}$ Hafer and Kutan (2002) showed that money, measured by M1 or M2, provides a good measure of the monetary policy stance.

${ }^{15}$ For a discussion on the relationship between money and prices refer to Hafer and Wheelock (2001) and Meltzer (2001).

${ }^{16}$ The monthly data on M2 are taken from the Banque De France statistical office, and the choice for the starting date is dependent on the availability of the data, as well as the fact that it coincides with the debut 
bank during the period. The absolute value computes each country's M2 volatility relative to the mean of its own series using the variance formula

$$
\text { Absolute Variance }(\Delta \mathrm{M} 2)=\sum_{\mathrm{t}=1}^{\mathrm{T}} \frac{\left(\Delta \mathrm{M} 2_{\mathrm{N}, \mathrm{t}}-\mu \Delta \mathrm{M} 2_{\mathrm{N}}\right)^{2}}{\mathrm{~T}}
$$

where $\mathrm{M} 2$ is the $\log$ of the money supply, $\Delta \mathrm{M} 2$ is money supply growth, $\mu \Delta \mathrm{M} 2$ is the mean of $\triangle \mathrm{M} 2, \mathrm{~N}$ is a particular EMU member country (or the ECB), and $\mathrm{T}$ is the number of monthly observations. The relative value computes each country's M2 volatility relative to the same-period value for the United States, rather than to the mean of the own series using

$$
\text { Relative Variance }(\Delta \mathrm{M} 2)=\sum_{\mathrm{t}=1}^{\mathrm{T}} \frac{\left(\Delta \mathrm{M} 2_{\mathrm{N}, \mathrm{t}}-\Delta \mathrm{M} 2_{\mathrm{US}, \mathrm{t}}\right)^{2}}{\mathrm{~T}}
$$

where US refers to the contemporaneous value for the United States.

I compute this second measure, variance relative to the United States, as a way to check the robustness of my results. Because the old national central banks and the new ECB operated in different time periods that may be structurally different, adjusting the data relative to the United States helps to make sure that any such difference is not driving my results. In other words, economic conditions in the post-ECB era may have been significantly different from the economic conditions in the pre-ECB era, and normalizing the variance around the United States can help to adjust for this, particularly because the Fed retained the same chairman during the period we consider.

of Alan Greenspan's chairmanship at the Fed, which is useful in later measures of the old central banks' activism relative to the Fed. I wish to thank Dr. Virginie Coudert from the Banque de France for providing me with the data. 
The results in Table 3.1 show that the volatility of M2 growth was the greatest for Italy, France, and Spain and the lowest for Austria, Belgium, and Germany. This implies that the old national central banks of Italy, France, and Spain were relatively more active than the national central banks in Austria, Belgium, and Germany. To check the robustness of these conclusions on the activism of the national central banks obtained from information on M2 volatility, I performed the same calculations (in absolute and relative terms) using monthly data on both nominal and real short-term market interest rates (r) as

$$
\text { Absolute Variance }(r)=\sum_{t=1}^{T} \frac{\left(r_{N, t}-\mu r_{N, t}\right)^{2}}{T}
$$

and

$$
\text { Relative Variance }(r)=\sum_{t=1}^{T} \frac{\left(r_{N, t}-r_{U S, t}\right)^{2}}{T}
$$

where the value subscripted US refers to the U.S. federal funds rate.

The last sets of columns in Table 3.1 show the results using interest rates as a measure of monetary activism and, lead to virtually the same conclusion as the monetary aggregate measures. Specifically, the results for both nominal and real interest rates reemphasize that the old national central banks of Spain, France, and Italy were more active than those of Austria, Germany, and Belgium. Moreover, the volatility of an EMU member country's nominal and real interest rates relative to the mean of its own series and also relative to the real and nominal federal funds rate in the United States gives virtually the same results. 
The last results presented in Table 3.1 are based on what might be considered simple measures of monetary activism. They are simple in that they incorporate information on all changes in these variables, not just those changes that were made by the central bank in response to short-run economic fluctuations. However, the simple measures of monetary activism and the more sophisticated results derived from the estimation of the Taylor rule model give us consistent findings.

As was discussed earlier, the charter of the new ECB explicitly guides it toward a less active, and more monetarist, policy stance. However, I thought it still might be worthwhile to compute my measures of monetary activism for the new ECB for comparison. Unfortunately, there are two problems. First, there exists a significantly shorter length of data available on the ECB relative to the old national central banks. Not only does this lessen the accuracy of any estimates, but it also makes it impossible to obtain meaningful estimates from the Taylor rule model. Thus, I am only able to present my simpler measures of activism for the new ECB. I am encouraged, however, that my earlier results suggest that these simpler measures appear to provide essentially the same results as does the more sophisticated Taylor rule model.

The second problem is that underlying economic conditions in the post-EMU era may have been significantly different from the underlying economic conditions in the pre-EMU era, clouding any meaningful comparison. Had the ECB been around during this earlier period, and had followed the same policy rules, its observed behavior might have either been more or less active than its observed behavior in the post-EMU era. This is precisely the reason why I have presented the measures both in absolute terms and also relative to the United States. By normalizing around U.S. policy, this might help to 
control for any differences in underlying economic conditions that might have caused a change in observed activism, particularly because the Fed retained the same chairman during the entire sample period. This procedure allows us to make sure that differences in the economic conditions between the two time periods are not driving the results I find by looking at the absolute measures. However, I still present the data for the absolute measures (the ones not relative to the United States) to show the strong robustness of my results regardless of whether I make this adjustment or not.

The results on relative volatility of the ECB's money supply growth rate, as well as the volatility of both nominal and real short-term market interest rates are shown in the final row of Table 3.1. ${ }^{17}$ For all of the indicators, the ECB shows much less activism than the old national central banks.

Figure 3.1 - Comparison of Monetary Activism Among Central Banks

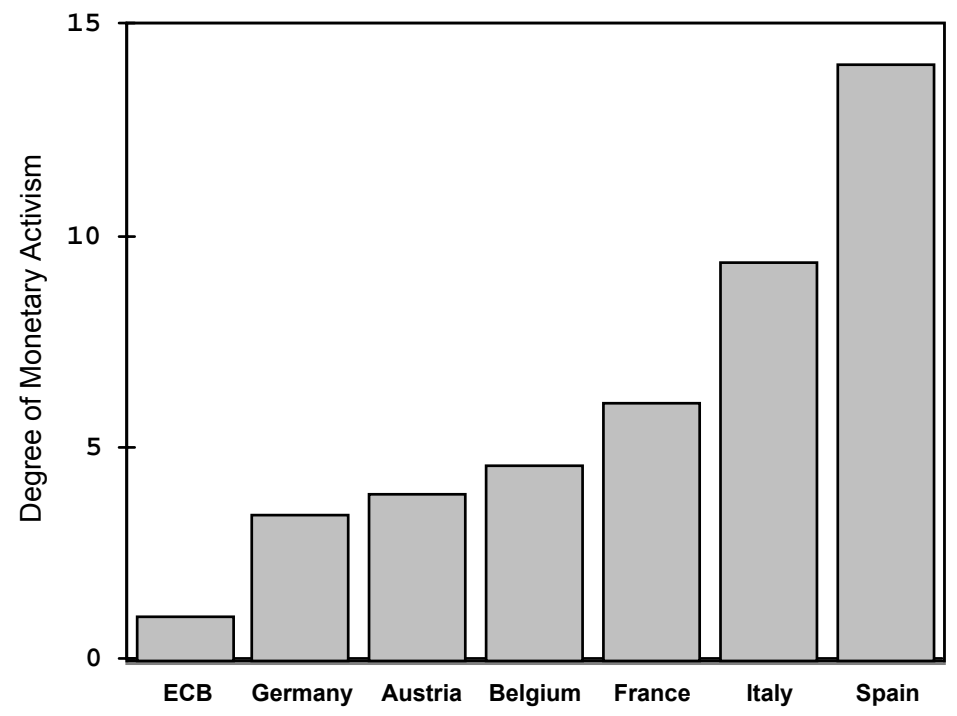

Note: The degree of activism is measured as the average of all simple measures presented in Table 3.1.

\footnotetext{
${ }^{17}$ For further comparisons, results are presented for the Federal Reserve Bank for the periods 1987:01 to 1998:12 and 1999:01 to 2001:12. The data on the U.S. M2 is from the Federal Reserve Bank of St Louis.
} 
Figure 3.1 presents data that make it somewhat easier to compare the degree of activism across old national central banks, and relative to the new ECB. Because I have several measures of monetary activism, I simply average them and the data illustrated in Figure 3.1 present a bar chart of these average values. In the figure, it is clear that monetary policy under the new ECB is less active than under the old national central banks. In particular, the ECB's monetary policy is much, much less active than the old national central banks of Spain and Italy. Recall, Salvatore (2002) found that of the EMU countries, Spain and Italy suffer from the most severe asymmetric shocks and would be the two countries that would suffer from greater economic instability after joining the EMU (because the new ECB will be unable to actively offset economic shocks like the very active national central banks did). ${ }^{18}$

In the only other related study discussing the activism of the new ECB relative to the old national central banks, Faust, Rogers, and Wright (2001) find that the ECB is a little less "hard-nosed" on inflation when compared to the old German Bundesbank. This is not directly at odds with my findings, though, because I attempt to look at activism, rather than the degree to which they attempt to maintain stringent price stability. However, it might suggest that it would be possible to construct alternative measures that might find the new ECB to be slightly more active than the old German Bundesbank, and perhaps almost equally as active as the old central banks of Austria and Belgium.

\footnotetext{
${ }^{18}$ The high degree of monetary activism of Italy and Spain is not only confirmed with regard to variance in monetary aggregates, but this is also reflected in the Taylor rule measure isolating the activism specifically with respect to responding to short-run economic fluctuations.
} 


\subsection{Have Their Economies Become More or Less Stable?}

My results suggest that the new ECB is a very inactive central bank, particularly when compared to the old national central banks of countries such as Italy, Spain, and France. In this section I attempt to see whether the economies of these countries have become more or less stable now that they are under a central bank that is less responsive to the short-run economic fluctuations they face. Several measures of the change in economic stability for these countries since the creation of the ECB are shown in the upper portion of Table 3.2. The lower portion of the table presents similar results for Denmark, Sweden, and the United Kingdom (the three countries who are part of the EU but who did not join the EMU). The results for these three countries will be presented and discussed at the end of this section, so for now readers may ignore the bottom portion of the table.

The volatility of the output gap, measured as the variance of the percent deviation of log-monthly industrial production from its trend, was used to measure the stability of each economy. The first column of Table 3.2 reports the changes in output gap variance measured as the variance post-EMU minus the variance pre-EMU. ${ }^{19}$ Thus, a negative number implies that the country's economy has become more stable under the new ECB, while a positive number would imply the economy has become less stable. The second column of data shows this change as a percentage of the old degree of variance.

\footnotetext{
${ }^{19}$ The pre-EMU period begins with the month each country joined the European Union and continues through 1998:12, and the post-EMU period spans from 1999:01 to the most recent data available (generally July 2001). An earlier draft of this paper used a much longer pre-EMU data period, but many readers were worried that the formation of the EU might itself have increased the stability of the countries and be driving my results. Thus, I have chosen to restrict the pre-EMU sample to only data since the formation of the EU. The results using the longer sample were virtually identical, although marginally stronger, than those presented here.
} 
Table 3.2 - Change in Economic Volatility Since Joining the EMU

\begin{tabular}{|c|c|c|c|c|c|c|}
\hline Country & $\begin{array}{c}\text { Change In } \\
\text { Variance of } \\
\text { Output } \\
\text { Gap }\end{array}$ & $\begin{array}{c}\text { Percentage } \\
\text { Change in } \\
\text { Output Gap } \\
\text { Volatility }\end{array}$ & $\begin{array}{c}\text { Percentage of } \\
\text { Pre-EMU Windows } \\
\text { With More Output } \\
\text { Volatility }\end{array}$ & $\begin{array}{c}\text { Change In } \\
\text { Variance of } \\
\text { Stock } \\
\text { Returns }\end{array}$ & $\begin{array}{c}\text { Percentage } \\
\text { Change in } \\
\text { Stock Market } \\
\text { Volatility }\end{array}$ & $\begin{array}{c}\text { Percentage of } \\
\text { Pre-EMU Windows } \\
\text { With More Stock } \\
\text { Market Volatility }\end{array}$ \\
\hline Countries with Relatively Nonactive National Central Banks Prior to EMU \\
\hline Germany & 1.64 & $48 \%$ & $0 \%$ & 0.0003 & $68 \%$ & $0 \%$ \\
Austria & -9.29 & $-47 \%$ & $61 \%$ & -0.0001 & $-8 \%$ & $28 \%$ \\
Belgium & -3.33 & $-20 \%$ & $23 \%$ & 0.0004 & $147 \%$ & $0 \%$ \\
\hline Countries with Relatively Active National Central Banks Prior to EMU & $19 \%$ & $7 \%$ \\
\hline France & -6.23 & $-79 \%$ & $68 \%$ & 0.0001 & $-36 \%$ & $40 \%$ \\
Spain & -12.13 & $-86 \%$ & $100 \%$ & -0.0003 & $-40 \%$ & $100 \%$ \\
Italy & -4.58 & $-66 \%$ & $100 \%$ & -0.0004 & $-40 \%$ \\
\hline \hline
\end{tabular}

\begin{tabular}{|c|c|c|c|c|c|c|}
\hline \hline Countries Who Are in the EU But Did Not Join EMU (Control Group) \\
\hline U.K. & 0.64 & $77 \%$ & $0 \%$ & 0.0001 & $27 \%$ & $0 \%$ \\
Denmark & -2.88 & $-29 \%$ & $31 \%$ & 0.0002 & $51 \%$ & $0 \%$ \\
Sweden & 2.69 & $28 \%$ & $0 \%$ & 0.0011 & $164 \%$ & $0 \%$ \\
\hline
\end{tabular}

Notes: For the period prior the EMU the start of the data set correspond to the time when the countries ratified their entry to the European Union. For Germany, Belgium, France, Spain, and Italy the pre-EMU period spans from 1992:11 to 1998:12. For Austria and Sweden pre- EMU period starts in 1993:01 to 1998:12. For the period post-EMU the data spans from 1999:01 to the most recent data available, which is generally July 2001.

The changes in the output gap variance show that the economies of Austria, Belgium, France, Spain, and Italy have all become more stable under the new ECB, in contrast to what the previous literature on asymmetric shocks predicted, particularly for Spain and Italy. Not only have these economies become more stable, the increase in stability appears to be closely related to the degree of activism of the old national central bank. It is precisely those countries like Spain and Italy that had the most active national central banks that have gained the most stability from moving under the relatively nonactive ECB. Using the output gap variance measure, only Germany has become less stable, although only slightly so. The fact that Germany was the least active of the old national central banks is again supportive of the predictions based on monetarist theory. While my data showed Germany to be slightly more active than the new ECB, recall that 
Faust, Rogers, and Wright (2001) suggested that the ECB was actually slightly more active than the German Bundesbank. If this is true, this finding of reduced stability is exactly in accord with the prediction of the monetarist position that as Germany moved under a more active central bank, that it lost economic stability.

The data presented in Table 3.2 is evidence in favor of the monetarist critique of the activist position because it suggests that the new ECB's inability to respond to these asymmetric shocks has actually resulted in greater economic stability for these countries. Most importantly, the increases in stability are undeniably bigger for the three countries whose old national central banks were the most active in pursuing short-run economic stabilization (France, Spain, and Italy) than they are for the three countries with the least active old national central banks (Germany, Austria, and Belgium). Thus, the countries experiencing the largest stability gains from being under the ECB are precisely those countries whose old national central banks were the most active. This would appear to be very strong evidence again in favor of the monetarist view that an active central bank, even though it has good intentions, results in less economic stability.

One obvious critique of these data is that it is possible that the post-EMU era has just simply been different from the pre-EMU era in that all of the world's economies have been more stable. However, this would not explain why it is precisely those countries with the most active old national central banks that have experienced the greatest gains in economic stability. Nonetheless, in an effort to ensure this alternative explanation was not responsible for driving my results, I decided to compare the output gap variance in the post-EMU period against all equally-sized smaller windows of data in my pre-EMU data. The third column of Table 3.2 reports the percent of pre-EMU windows that had higher 
output gap variances compared to the single post-EMU window. It is interesting to note that Italy, France, and Spain had $100 \%, 68 \%$, and $100 \%$ of their pre-EMU window variances that were higher than the post-EMU variance, respectively. This means for Italy and Spain the period after joining the EMU has been characterized by more economic stability than any other equally lengthy time period prior to the EMU. Thus, this group of countries with the most active old national central banks is exhibiting greater stability under the ECB than in the vast majority of equally-sized windows in the pre-EMU period. On the other hand, the percentages for Germany, Belgium, and Austria (the three countries with relatively inactive old national central banks) are substantially lower at $0 \%, 23 \%$, and $61 \%$, respectively. Again, this group of countries has experienced either none, or at best small, stability gains compared with the countries with the more active national central banks.

To further check the robustness of my results, Table 3.2 also reports similar data for the volatility of financial markets in these countries measured with each country's monthly stock market index (including withholding taxes). ${ }^{20}$ This is an interesting second variable to consider because not only is financial stability closely linked to the overall stability of the economy, but also because stock prices incorporate a significant amount of discounted information about future economic conditions. A decrease in the volatility of stock market returns implies greater stability of the financial system. The

\footnotetext{
${ }^{20}$ The period pre-EMU covers the period starting with the country's ratification to join the European Union to 1998:12 and the period post-EMU covers the period 1999:01 to 2001:07. The data are from Morgan Stanley Capital International.
} 
final three columns of Table 3.2 reports the changes in the volatility of stock market returns, again measured as the variance post-EMU minus the variance pre-EMU. ${ }^{21}$

Using this alternative measure of economic stability generally tells the same story. The two countries with the most active national central banks, Spain and Italy, have gained substantial economic stability since joining the EMU. The stability of stock market returns has also become more stable for Austria, although by not nearly as much. The results for the country with the least active old national central bank, Germany, again suggest a slight decrease in economic stability since joining the EMU. The stock market results for Belgium and France are the only ones that don't correspond to the same conclusion reached from measuring economic stability by examining the output gap.

At this point, the most compelling counter hypothesis to the one I present is that all European economies have simply become more stable in the post EMU period (perhaps because of the EU itself). The obvious test of this is to compare the change in economic stability for these EMU countries to the three European countries that are in the EU but did not chose to join the EMU (United Kingdom, Denmark, and Sweden), and instead kept their own national central banks in place. The results for these three countries that serve as a 'control group' are presented in the lower portion of Table 3.2. Since these countries did not join the EMU, and are under the same national central bank as they were before, the changes in economic stability for them should be a benchmark to which the EMU countries can be compared.

The output gap measure shows that two of these three non-EMU countries have had less economic stability in the post-EMU period than the pre-EMU period, while the

\footnotetext{
${ }^{21}$ Stock market return is calculated as the log difference of the stock market index.
} 
stock market volatility measure shows all three to now have less economic stability. This data clearly shows that the stability gains I find for the EMU countries were not similarly experienced by the other EU countries that did not join the EMU, thus ruling out this competing hypothesis that might explain my findings.

The evidence presented in this section strongly suggests that there is little evidence to support the previous literature's contention that these EMU economies (particularly Spain and Italy) would become less stable after coming under the new ECB because of its inability to tailor monetary policy to the needs of each country. In fact, the evidence seems to suggest just the opposite. I find that the economies of these countries have become more stable under the new ECB. This has important implications for the future of the EMU because quite a substantial body of literature has used this idea as the basis for an argument that the EMU would eventually collapse as these countries left the EMU because of the decreased economic stability they would experience.

My empirical results for Spain and Italy can be explained in one of two ways: either Spain and Italy have benefited from being under a central bank that is unable to respond to their asymmetric shocks (the monetarist position), or the two countries have yet to experience asymmetric disturbances at all. The fact that both Spain and Italy have experienced more output stability in the post-EMU era than in all of the equally-sized periods of time during the twenty years prior to the formation of the EMU seems to suggest the former, particularly since during this same post-EMU period there was less output stability for the control group countries such as Sweden and the United Kingdom than during the pre-EMU period. Thus, I believe the data show clearly that the inability of the new ECB to be able to react to all of the asymmetric shocks occurring in these 
countries has resulted in more stability, not less - a finding that is consistent with a monetarist view of monetary-policy ineffectiveness.

Also consistent with the hypothesis I derive from the monetarist position is my finding that the EMU countries whose economies have exhibited the greatest gains in economic stability since coming under the new ECB are precisely those countries whose old national central banks were the most active in pursuing short-run economic stabilization. In particular, Italy and Spain, the two countries with the most active national central banks, have been the ones that have shown the greatest improvements in stability, while at the same time these stability gains have not occurred for countries in the EMU who already had a relative inactive national central bank (like Germany) nor for countries who are in the EU but did not join the EMU (like Sweden and the U.K.).

\subsection{Conclusion}

The results of this paper have significant implications both for the future of the EMU specifically, and for the effectiveness of activist stabilization policy more generally. Despite the predictions that these European economies would begin to suffer wider swings in economic activity under a common central bank that is unable to 'optimally' respond to the asymmetric shocks faced by each nation, they have not. In fact, I find that all of these economies have become more stable after coming under the ECB with the exception of Germany who already had a relatively inactive central bank. Because this prediction of increased instability was the basis for predictions that claimed that the EMU would be doomed in the long run, my results suggest a much rosier picture for the future of the EMU. 
My explanation for the observed data is that despite good intentions, activist monetary policy is simply unable to deliver on its promise, and that activist policy is actually counterproductive to the achievement of economic stability. If this explanation is correct, it brings into question the entire theory of optimum currency areas (hereafter, OCA). If common central banks are activist, but react to the average economic conditions in the entire area, and these activist policies are actually counterproductive, then it would appear that merging unlike economies into a common currency area would actually result in more stability than would merging similar economies because it would result in a less active common central bank. One can easily imagine how the calculus of an OCA model would change after adding in monetary policy timing errors and a central bank that responds to the average economic conditions. My conclusions with regard to OCA theory can be viewed as supportive of the conclusions reached in the relatively new 'endogenous OCA' literature pioneered by Frankel and Rose (1998), Rose (2000), and Rose and van Wincoop (2001). ${ }^{22}$

Not only do my results find increased economic stability after coming under the relatively inactive $\mathrm{ECB}$, but they also show that the countries experiencing the greatest gains in stability are precisely those whose old national central banks practiced the

\footnotetext{
${ }^{22}$ Frankel and Rose (1998) argue that sharing a same currency results in closer trade relations that cause the business cycles across countries to converge. Because synchronized business cycles are one of the major criteria for the creation of an Optimal Currency Area (OCA), their findings emphasize the fact that the conditions of an OCA may be met ex post, rather than ex ante. Rose (2000), and Rose and van Wincoop (2001) reiterate the economic benefits experienced by a country that joins a currency union and the endogeneity of the OCA criteria. Their conclusion meets mine in that the choice of joining the EMU should not depend on the optimum currency area criteria. Like me they believe that the benefits of a currency union have been under-stated in the literature and, that the potential gains of joining the EMU should influence more countries to give up their monetary sovereignty.
} 
highest degree of activist stabilization. This is highlighted by the stability gains of Italy and Spain, whose national central banks were characterized by highly active responses to short-run output fluctuations. This data is particularly convincing when these countries are compared to countries that used to have relatively nonactive central banks (such as Germany) and to the countries in the EU that did not join the EMU (United Kingdom, Sweden, and Denmark). This is my strongest evidence against the alternative explanation that all of these countries have simply had greater underlying economic stability in the post-EMU era. The increase in stability that I find is consistently and predictably related to the degree of activism of the old national central bank, and is not simply a uniform improvement across all of the countries. The countries that have had the greatest reductions in monetary activism have gained the most in economic stability. The results simply and clearly suggest that a less active central bank that is committed to price stability results in greater macroeconomic stability.

The underlying implications of this latter finding should be obvious. Activist stabilization policy on the part of central banks, while well-intentioned, actually leads to less economic stability. Because the effectiveness of activist monetary policy has been an area of significant debate among economists over the past three decades, being able to find such a unique opportunity to test it in such a clear, straightforward manner has significant value. Monetary theories based on mathematical models that build in an assumption that monetary activism is effective (such as the asymmetric shock theory for the EMU or theories of optimum currency areas) are simply unable to deliver predictions that fit the real-world data for the EMU. I hope that my findings would encourage readers 
to be skeptical of the predictions of monetary theories that do not incorporate the monetarist critique and simply assume the effectiveness of monetary activism.

Of course, it has only been three years since the formation of the EMU, a period of time finally long enough to begin to test for many of the economic changes that have occurred as a result of this transformation in Europe. However, as more time passes, and greater spans of post-EMU data become available, more reliable estimates will be possible. While the data now available are sufficient from an econometric standpoint to allow us to get reliable estimates, more data always improves the accuracy of the estimates obtained from any empirical analysis. I am confident that the study of the effects of the formation of the EMU will generate many new and significant insights that will allow the profession to settle some of the major debates remaining in macroeconomic theory about the effectiveness of monetary activism. 


\section{Chapter 4}

\section{The Relationship Between Currency Competition and Inflation}

\subsection{Introduction}

In 1960, Nobel laureate M. Friedman published A Program for Monetary Stability in which he investigated the reasons why governments should regulate monetary and banking arrangements. Friedman stated that only government issuers of currency have the ability to limit the amount of money supplied as a means to maintain the value of their currency higher than the marginal printing costs. Friedman argued that if monetary arrangements were left to market forces and competition, there would be a possibility for hyperinflation caused by private issuer's incentives to print excess amounts of their currency.

In 1976, another Nobel laureate F. A. Hayek published The Denationalization of Money in which he argued for a competitive approach to the provision of money as an alternative to the established government-run standard. Since then, many economists have become intrigued by the idea of a free market for money, where competition to issue currencies would be unregulated. Hayek argued that the "natural" invisible hand would produce a spontaneous order in the money market that cannot originate from a humandesigned monetary authority.

According to Adam Smith's theory of the invisible hand, when left undisturbed, markets are able to coordinate the actions of self-interested individuals and direct such individuals toward activities that promote general welfare. Competitive market forces, by establishing a "reward-penalty" (profit-loss) structure, induce the supply of goods that are strongly desired by consumers relative to their cost of production. As Dowd (1988) 
emphasizes, the money industry, is not fundamentally different from other commodity markets, and therefore, should be analyzed using the same tools. ${ }^{23}$ In the same way that competition leads companies to maintain the quality of their products, monetary arrangements that are left to the market, will give strong incentives to competitive issuers of currency to maintain the quality (value) of their currency. ${ }^{24}$ Although competitive issuers have an incentive to collect seigniorage on their money creation, the issuers will need to preserve public confidence, and competition should result in only "normal" rates of return. As defined by Cukierman (1992) seigniorage is the amount of real purchasing power that currency issuers can extract from the public by printing money. When seigniorage is excessive, the burden of lost purchasing power should cause self-interested consumers to switch away from the currency to a different one.

Considerable controversy surrounds the effect of barriers to entry in the money industry. Some economists argue that the existence of entry barriers is a source of inefficiency because it does not allow the optimization of the value of a nation's currency. In contrast, other economists think that the entry barriers are necessary to prevent rapid inflation or even hyperinflation. ${ }^{25}$ The purpose of this chapter is to empirically address the relationship between currency competition and inflation. ${ }^{26}$

\footnotetext{
${ }^{23}$ Throughout this study I shall use the term "money industry" to refer to all money-producing firms, whether private or public.

${ }^{24}$ The value of a currency can be measured by its purchasing power.

25 England (1997) summarizes the opposition to currency competition and states the basic argument that as the cost of producing money decreases, the money supply would expand faster, causing rapidly increasing prices. For other literature on the opposition to currency competition refer to Friedman (1960) and Pesek and Saving (1967). Also, I would like to avoid any confusion about the meaning of inflation by citing Kernmerer's (1934) definition of inflation that was quoted in Bryan (1998) and stated that "inflation exists in
} 
Most economists agree that the only sustainable long-term objective of monetary policy is maintaining the purchasing power of money. ${ }^{27}$ Maintaining the purchasing power of money, or in other words, achieving a low level of inflation, promotes economic prosperity. In his address to the Federal Reserve Bank of Kansas, Wim Duisenberg (1999), the president of the newly created European Central Bank reaffirmed his belief that low inflation is necessary for maintaining sustainable output growth and high levels of employment. Duisenberg made it clear that the European Central Bank believes that even moderately high rates of inflation are harmful to economic growth. This argument is shared by Barro (1996) who found a negative relation between inflation and economic performance in 100 countries from 1960-1990. Also, Carlson (1997) shows that the Fed's actions aimed at maintaining a low inflation environment are associated with substantial economic growth.

Hence, the main question that this chapter tries to answer is whether competition in issuing currency will result in lower inflation. Specifically, this chapter examines the

a country whenever the supply of money...increases relative to the demand for the media of exchange, in such a way as to bring about a rise in the general price level."

${ }^{26}$ This study is not attempting to look at all issues involved in the abandonment of central banking and the adoption of a free banking system with currency competition. For a discussion on other related issues, such as bank runs and panics, natural monopoly, and counterfeiting, which are all outside the scope of this study, refer to Williamson (2002), Friedman and Macintosh (2001), Dowd (1992), Selgin (1988), and Sechrest (1993).

${ }^{27}$ Refer to Altig (2002) for a discussion on the importance of preserving the purchasing power (value) of a nation's currency. 
constraints that a currency issuer faces when governmental restraints are placed on currency competition within the country's borders and from abroad. ${ }^{28}$

The set up of this chapter is as follows. Section 2 will review some of the literature on free banking with an emphasis on actual international experiences, and will present some relevant literature on foreign currency competition. Section 3 will analyze the average rates of inflation for nine countries under free banking when compared to central banking. Section 4 will provide empirical evidence showing the effect of foreign currency competition on the average inflation rates of OECD countries. Finally, Section 5 will present concluding remarks and policy implications.

\subsection{Relevant Literature}

As defined by Selgin and White (1994) a free-banking (laissez-faire) monetary regime is a regime without a state-sponsored central bank, where no barriers are placed on private issuers of currency to enter or exit the money industry. Also, there would be no government mandated capital requirements to enter the money industry. Although no current freebanking regime exists in the world, free banking has existed in the past for many countries. The free-banking regimes that did exist were not purely laissez-faire, because they were characterized by some government regulation. However, all of the free-banking arrangements were characterized by simultaneously having more than one currency issuer.

\footnotetext{
${ }^{28}$ Currency competition can be of two kinds. First, competition to the domestic currency can come from abroad in the form of currencies supplied by foreign central banks. Second, the currency competition can come from inside the borders from private suppliers.
} 
Thus, the barriers that existed did not inhibit competition as much as do the entry barriers currently in place under central banking. ${ }^{29}$

The emergence of public choice theory, with its skeptical view about government's role in the economy, has renewed support for the analysis of free banking. This literature regards the activity of central bankers with skepticism, and argues that the utility function of central bankers includes not only a concern for public interest, but also the pursuit of self-interest. Tullock (1975) compares the incentives of private currency issuers to the incentives of governments. He hypothesizes that governments tend to discount more heavily the distant gains of economic growth than does the private sector. Therefore, when governments have the exclusive right to supply money, they face a lack of incentives to keep the level of inflation low because the gains of devaluations are immediate. Hayek (1976) emphasizes that when the population is left with no alternative currency but the one that government provides, then the central monetary authority has less incentive to provide sound money. More specifically, central bankers, because of political incentives, begin to use seigniorage regularly to collect revenues and finance government expenditures. Hayek thinks that the inflationary pressure is a political force that monetary authorities have never been able to resist, and his only hope for stable money is to "find a way to protect money from politics." The bottom line is that the rate of money production, under a central bank, can be driven by other incentives besides the public interest. ${ }^{30}$ Ultimately, the public choice

\footnotetext{
${ }^{29}$ It should be noted that central-banking regimes are characterized by one government-monopolized issuer of the domestic currency, which is the opposite of the competition that is prevalent under free-banking regimes.

${ }^{30}$ Shughart and Tollison (1983) present evidence of the bureaucratic incentives of the Federal Reserve Bank. Specifically, they show that every time the Federal Reserve Bank hires one worker, the stock of high-powered money rises by $\$ 362,000$.
} 
explanation for the establishment of a government-run monopolistic central-banking system is that it provides the government with a source of revenue. ${ }^{31}$

Many economists have looked at the economic outcomes of countries with past experiences in free banking in an attempt to find an economic justification for the elimination of free banking. The majority of these studies find that the switch to centralbanking regimes, as characterized by pure government monopoly currency providers, was not economically warranted. In fact, White (1992) praised the very unregulated Scottish experience of laissez-faire banking in the nineteen century for its economic performance. The money industry in Scotland was self-regulated, highly competitive, and ultimately promoted strong economic growth of the Scottish society. The suppression of this wellfunctioning regime had nothing to do with economic performances or monetary instability, but followed from the pressure of English theoreticians. Similarly, Weber $(1988,1992)$ analyzes the long-standing Swiss laissez-faire regime, which lasted approximately one hundred years. The competitive issue of money in Switzerland was characterized by low inflation, and provided a secure monetary system.

Continuing the research on laissez-faire regimes, Nataf (1992) surveys the literature on the experience of free banking in France. This period of free competition in the French money industry is unanimously considered efficient according to the literature Nataf surveyed. Also, the French money industry was shown to be highly stable and helped to put an end to the long-running inflation caused by the monopolized currency supplied by the

\footnotetext{
${ }^{31}$ Weber (1992) contrasts the free-banking system and central-banking system. He believes that central banks can inflate at a profit because currency substitution is limited. However, private issuers, in a freebanking regime, face negative marginal revenue of inflating because of the possibility that consumers will substitute away from their currency. This profit incentive would lead each regime to experience a different inflationary environment.
} 
previous monarchial regime. Nataf (1992) stated that "an arbitrary act of authority" put an end to the free-banking system in France, and the Banque de France was created to be the sole supplier of money to fund Napoleon's ambitions.

Selgin (1988) succinctly characterizes the Australian episode of free banking as a period of time that was associated with fairly stable prices, while the monopolization of the Australian currency resulted in a "dramatic" rise in prices. Dowd (1993) develops the Australian free-banking experience more exhaustively. He argues that the results of this regime were all positive, by fostering stability up until non-systemic bank failures produced an opportunity for inept government interventions, which aggravated the banking crisis and ultimately led to the creation of the central bank. In an overview of the world history of free banking, Schuler (1992) summarizes the free-banking experience of approximately sixty countries. He concludes that in general these competitive monetary arrangements were stable and were dismissed for political reasons, which were supported by mainstream economic theory.

Competition of private currency providers within a country's domestic borders is not the only form of currency competition. Competition can also originate from foreign central banks. Tullock (1975) hypothesizes that governments who want to collect revenue through inflation prefer that no substitutes to their currency develop, even foreign alternatives. He says that by making foreign currencies illegal for citizen to hold, governments can make the transaction cost of using the foreign currency very high. Facing 
high transaction costs, individuals will not use or hold alternative currencies, and will only demand the government issued currency. ${ }^{32}$

Vaubel (1990) lists two mechanisms by which foreign currency competition can lower domestic inflation. First competition increases the incentives for the domestic monetary authority to maintain its market share in the international financial market. Therefore, the monetary authority has incentive to keep the value (or purchasing power) of its currency high. Second, public opinion may pressure the domestic government to maintain low inflation, as they will want to replicate the example set by other lowinflationary countries.

Camera, Craig, and Waller (2001) theoretically show that if a government fails to adopt policies that maintain the value of its domestic currency, the domestic population would choose to use a more stable foreign currency as its medium of exchange.

Craig (1996) relates the Russian experience of 1992-1995 to illustrate his claim that competition, provided by stable foreign currencies, forces the monetary authority to lower inflation and concentrate more of its efforts in providing a sound domestic currency. In a country where the population rebelled and established the dual-currency system (dollar/ruble) by holding dollars illegally, the only way for the Russian monetary authority to collect seigniorage, was for the ruble to become the dominant currency again. The monetary authority had to decrease the inflation rate of its currency to regain its purchasing power and increase the population's demand for the domestic ruble. Generally, the Russian experience shows that a total deregulation of the domestic monetary system may not be needed in order to achieve low levels of inflation. Rather, competition from foreign

\footnotetext{
${ }^{32}$ Weber (1988) states that even during the German hyperinflation era, there was still demand for the central bank currency mainly because currency competition was forbidden, outright.
} 
currencies may provide the domestic currency issuer with the incentives to keep inflation in check.

\subsection{Free-Banking Era}

In this section, calculations of annual average inflation rates during the free-banking eras that occurred in Australia, Canada, France, Italy, New Zealand, Spain, Switzerland, Sweden, and the United States are presented and compared to the average annual inflation rates after the creation of each country's national central bank. ${ }^{33}$ Many economists have theorized that free banking and inflation are related. For example, Friedman (1960), and Pesek and Saving (1967) hypothesize that competition among private suppliers will increase the money supply infinitely (leading to hyperinflation) ultimately because the marginal cost of each issuing currency would be zero. According to Pesek and Saving, "a competitive money industry is suicidal." In contrast, Klein (1974), among others, theoretically refutes the possibility that private issuers would be inclined to inflate their currency. Also, Schuler (1992) claims that long-term price stability was greater under free banking than it has been under central banking. Many studies have succinctly and anecdotally shown that private competition has not led to inflationary environment in many countries. For example, McCallum (1989) analyzes the wholesale price indices in Belgium, Britain, France, Germany and the United States and shows that these countries had no inflationary tendency during periods that included their free-banking regimes.

\footnotetext{
${ }^{33}$ Because the free-banking areas mostly occurred over one hundred years ago, reliable historical data were available for only nine of the OECD countries.
} 
Previous studies have analyzed historical experiences of free banking to see if free-banking periods are associated with large price changes but this study is the first to measure the average rate of inflation under free-banking and central-banking regimes and statistically compare the two regimes.

Table 4.1 presents the average annual inflation rates during free-banking (competitive currency suppliers) and central-banking (government monopolized currency provider) eras for nine OECD countries for which data are available. ${ }^{34}$ The inflation rate is calculated by using the percent change in the consumer price index (CPI) as follows: ${ }^{35}$

$$
\text { Inflation rate }=\frac{\mathrm{CPI}_{\mathrm{t}}-\mathrm{CPI}_{\mathrm{t}-1}}{\mathrm{CPI}_{\mathrm{t}-1}} * 100
$$

Referring to Table 4.1, the third column shows the average inflation rate during the free- banking era, and the fourth column shows the average inflation rate after central banking began. The fifth column of Table 4.1 reports the change in the average inflation rate for each country, which is measured as the average inflation during central banking minus the average inflation during free banking. Thus, a positive number implies that the rate of inflation under central banking is higher than the rate under the free-banking regime.

\footnotetext{
${ }^{34}$ All data are from Mitchell's various volumes of International Historical Statistics. The set of countries under study are the only OECD countries for which I was able to locate data during their free-banking regime time period.

${ }^{35}$ For most of the countries under study CPI was not available or offered few years only for the period of time I was interested in. Therefore, for those countries I used the percent change in the wholesale price index (WPI) as a measure of the inflation rate.
} 


\section{Table 4.1: Average Inflation During the Free-Banking Era and After Central Banking Began.}

\begin{tabular}{|c|c|c|c|c|c|}
\hline Country & $\begin{array}{c}\text { Free Banking } \\
\text { Years }\end{array}$ & $\begin{array}{c}\text { Average Annual } \\
\text { Inflation Rate } \\
\text { During Free Banking }\end{array}$ & $\begin{array}{c}\text { Average Annual } \\
\text { Inflation } \\
\text { Rate After } \\
\text { Central Banking } \\
\text { Began }\end{array}$ & $\begin{array}{c}\text { Change in } \\
\text { Annual Inflation } \\
\text { Rate }\end{array}$ & $\begin{array}{c}\text { Absolute } \\
\text { t-ratio }\end{array}$ \\
\hline Australia & $1862-1911$ & -0.50 & 4.36 & 4.86 & $5.19^{* * *}$ \\
\hline Canada & $1849-1933$ & 0.95 & 4.67 & 3.72 & $2.57^{* * *}$ \\
\hline France & $1796-1848$ & -0.63 & 5.88 & 6.51 & $2.58^{* * *}$ \\
\hline Italy & $1832-1894$ & 0.38 & 13.14 & 12.76 & $1.75^{*}$ \\
\hline New Zealand & $1892-1933$ & 1.81 & 5.70 & 3.89 & $4.23^{* * *}$ \\
\hline Spain & $1844-1874$ & 1.32 & 4.95 & 3.63 & $1.96^{* *}$ \\
\hline Switzerland & $1834-1907$ & 0.35 & 4.54 & 4.19 & $2.88^{* * *}$ \\
\hline Sweden & $1831-1901$ & 0.50 & 4.12 & 3.62 & $4.12^{* *}$ \\
\hline United States & $1782-1914$ & 0.49 & 3.39 & 2.90 & $1.93^{*}$ \\
\hline
\end{tabular}

Notes: The starting date of the free-banking years does not always reflect the starting date of the free-banking era, but the first year of the free-banking era when data were available.

Significance levels represented by: ${ }^{* * *} 1 \%,{ }^{* *} 5 \%,{ }^{*} 10 \%$

In order to check the significance of the findings, a difference-in-mean test was performed, which included the following null and alternative hypothesis to be tested:

$$
\begin{aligned}
& \mathrm{H}_{0}: \mu_{1}=\mu_{2} \\
& \mathrm{H}_{\mathrm{A}}: \mu_{1} \neq \mu_{2}
\end{aligned}
$$

Where $\mu_{1}$ is the average annual inflation rate during the free-banking years, and $\mu_{2}$ is the average annual inflation rate after the central-banking system began. I use a standard twotailed t-test where the computed t-statistic follows the following calculation:

$$
\begin{gathered}
\mathrm{t}_{\text {computed }}=\frac{\mu_{1}-\mu_{2}}{\sqrt{\mathrm{s}^{2}\left(\mathrm{n}_{1}+\mathrm{n}_{2}\right) / \mathrm{n}_{1} \mathrm{n}_{2}}} \\
\text { where } \mathrm{s}^{2}=\frac{\left(\mathrm{n}_{1}-1\right) \mathrm{s}_{1}{ }^{2}+\left(\mathrm{n}_{2}-1\right) \mathrm{s}_{2}{ }^{2}}{\mathrm{n}_{1}+\mathrm{n}_{2}-2}
\end{gathered}
$$

where $n_{1}$ is the number of years during the free banking era, $n_{2}$ is the number of years after central banking began; and $s_{1}$ and $s_{2}$ are the inflation rate variances during the free-banking 
and central-banking eras respectively. The degree of freedom is measured as $\left[\mathrm{df}=\mathrm{n}_{1}+\mathrm{n}_{2}-\right.$ 2]. For all countries, the null hypothesis of equal average annual inflation rates was rejected at the $10 \%$ significance level. ${ }^{36}$

My results, find that in each country for which data are available, average inflation during the free-banking period was significantly lower than inflation under central banking. Italy and France experienced the largest increases in inflation after moving to central banking. Interestingly, Schuler (1992) claims that both of these countries abandoned their free-banking regimes strictly for the purpose of gathering revenue. Although, the United States experienced lower rates of inflation during its free-banking era, it had the smallest increase in inflation rates after moving to central banking. It is interesting to note that, according to Schuler (1992), the United States ranked as the most regulated of all "free" banking systems. This result implies that the switch from a highly regulated competitive money industry to a monopolized government currency provider perhaps does not as large of a change in inflation.

The findings in Table 4.1 highlight the fact that competition in the supply of money among private issuers results in lower inflation rates than does a central bank. Furthermore, these findings directly refute the claims of Friedman (1960), and Pesek and Saving (1967) that competitive private currency providers would have a tendency to over-issue their currencies ultimately producing hyperinflationary pressures.

\footnotetext{
${ }^{36}$ For two countries the null hypothesis was rejected at the $10 \%$ level (U.S.A and Italy), for one country (Spain) the null hypothesis was rejected at the $5 \%$ level, and for the other six countries (France, Australia, New Zealand, Canada, Sweden and Switzerland) the null hypothesis was rejected at the $1 \%$ level.
} 
Table 4.2: Output Growth During the Free-Banking Era and After Central Banking Began.

\begin{tabular}{|c|c|c|c|}
\hline Country & $\begin{array}{c}\text { Output Growth } \\
\text { during Free } \\
\text { Banking }\end{array}$ & $\begin{array}{c}\text { Output Growth After } \\
\text { Central Banking } \\
\text { Began }\end{array}$ & Absolute t-ratio \\
\hline Australia & 0.047 & 0.078 & 1.35 \\
\hline France & 0.004 & 0.013 & 1.12 \\
\hline Italy & 0.006 & 0.015 & 0.88 \\
\hline Spain & 0.017 & 0.013 & 0.79 \\
\hline Sweden & 0.017 & 0.013 & 0.61 \\
\hline United States & 0.019 & 0.227 & 0.23 \\
\hline
\end{tabular}

Notes: The starting date of the free-banking years does not reflect the starting date of the free-banking era, but the first year of the free-banking era when data on industrial production or GDP were available. Significance levels represented by: ${ }^{* * *} 1 \%,{ }^{* *} 5 \%,{ }^{*} 10 \%$

The evidence presented above suggests that free banking is associated with lower inflation rates than is central banking. One potentially complicating factor, however, is that following the equation of exchange, the rate of real output growth can affect the relationship between money growth and inflation. Specifically, for any given level of money growth, inflation will be lower during periods of faster real output growth. Thus, it is necessary to see whether a difference in the average rate of real output growth can serve as an alternative explanation of the results. Data on GDP or industrial production was available for six of the nine countries and the results of the difference in means test for output growth rates between the free-banking and the central-banking eras are presented in Table 4.2. ${ }^{37}$ For none of these countries does there exist a significant difference, thus it is possible to eliminate faster real output growth as a source of the differing rates of inflation.

One of the main objectives of this study is to give empirical evidence that sheds light on the debate over whether private issuers have a tendency to over-issue their

\footnotetext{
${ }^{37}$ All data on industrial production and GDP are from various volumes of Mitchell's International Statistics.
} 
currency, which in turn will lead to higher levels of inflation. My results show that the freebanking opponents' argument that private competition will lead to hyperinflation is unfounded. In fact, the inflation rates under competition are significantly lower than when central banks have the monopoly over currency issuance. ${ }^{38}$ As mentioned by Selgin (1988), and illustrated here, higher inflation seems to be a tendency of centralized banking. These results suggest that competition among currency suppliers provides consumers with choices that enhance their well being.

\subsection{Foreign Currency Competition}

In this section, I extend my analysis by exploring how foreign competition influences a domestic central bank's behavior. In particular, I attempt to see whether competition from foreign central banks leads to less domestic inflation, or, in other words, to a sounder domestic currency.

For this analysis I use an index that measures the freedom of a country's citizens to hold foreign currencies constructed by Gwartney and Lawson (2001). Their index, called the freedom to use alternative currency, is an average of two indices. The first averaging index, called ownership of foreign currency, gives a value of ten to countries that allow foreign currency accounts without restrictions, both domestically and abroad, and a zero to countries where these accounts are restricted. Also, if foreign currency bank accounts are permissible domestically, but not abroad, (or vice versa), the index rating was five. The second averaging index is called the black market exchange rate, and allocates a rating of ten to countries where domestic currency is fully convertible without

\footnotetext{
${ }^{38}$ A difference of variance test, comparing the variance of inflation rates during the period of free banking to the period of central banking, is performed. Results are reported in Appendix B.
} 
restrictions. The rating decreases toward zero as the black market exchange premium increases toward fifty percent.

\section{Figure 4.1: Average Annual Inflation and Freedom to Use Alternative Currencies (1970-1999)}

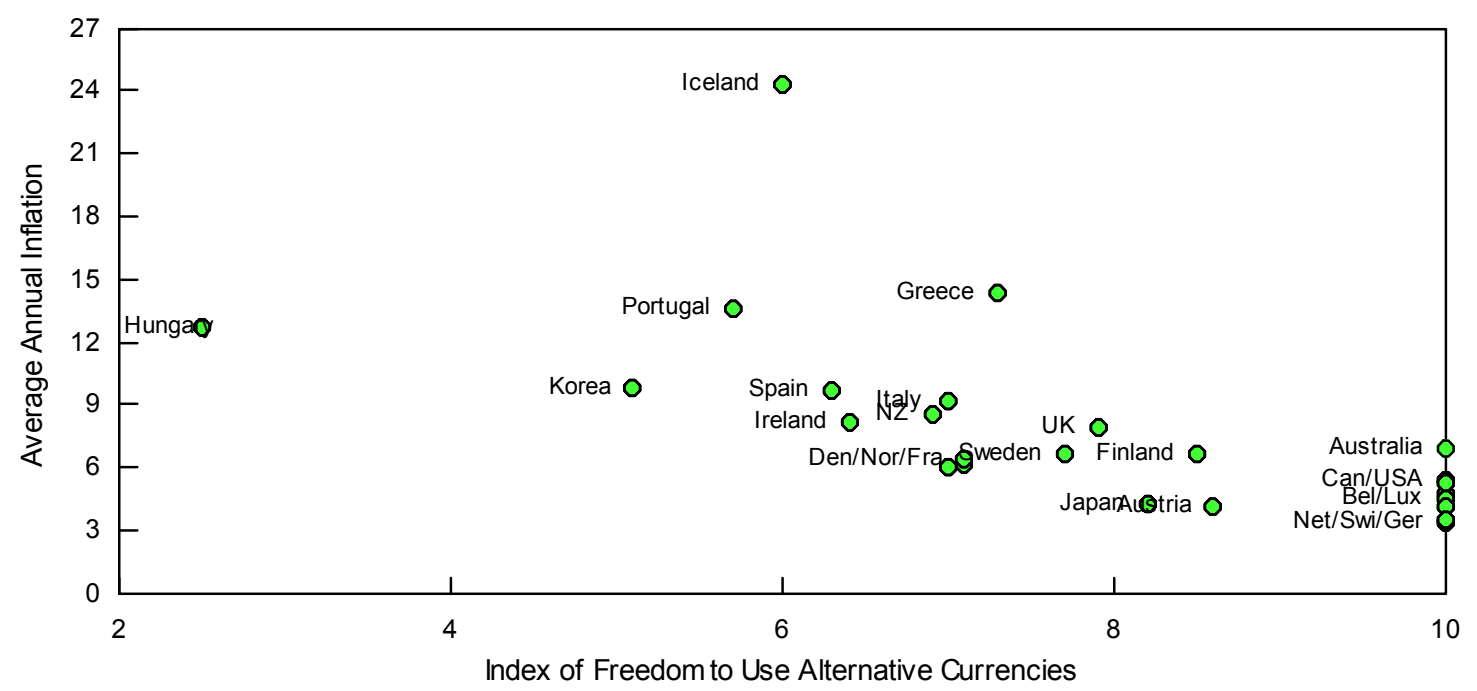

This measure of competition is consistent with the more theoretical literature pertaining to foreign currency competition, such as Tullock (1975) and Vaubel (1986). I then attempt to correlate this index with the average annual inflation rate for all OECD countries from 1970 to $1999 .^{39}$ Figure 4.1 illustrates the strength of the correlation in this data. $^{40}$

In order to support the findings that are illustrated in the figure 4.1 , the average inflation rates were regressed solely on the index of freedom to use alternative currencies and results are presented in the first column of Table 4.3. The index of freedom to use alternative currencies is negative and significant at the 5\% level. This implies that greater

${ }^{39}$ Out of the 30 OECD countries, only the Czech Republic and the Slovak Republic are absent from the analysis, as those countries have been formed in the early 1990s.

${ }^{40}$ Mexico, Turkey and Poland have experienced hyperinflation during many years of the sample period. These countries appear to be significant outliers, and were omitted from the figure. 
freedom of citizens to hold foreign currency leads to less inflation. To investigate this relationship more rigorously I then add to this basic model a number of factors that have been identified by previous literature, in particular by Banaian, Burdekin and Willett (1995), as significant in explaining variation in inflation rates. This expanded model takes the form:

$$
I_{i}=\alpha+\beta_{1} I F A C_{i}+\beta_{2} G_{i}+\beta_{3} \text { TRADE }_{i}+\beta_{4} Y_{i}+\beta_{5} G_{I N I}+\beta_{6} I N D_{i}
$$

where, $I_{i}$ is the annual average inflation rate for country i. $\mathrm{IFAC}_{\mathrm{i}}$ is the Index of Freedom to Use Alternative Currencies for country $i, G_{i}$ is the government deficit as a share of GDP for country $i$, TRADE $_{i}$ is the volume of trade as a share of GDP for country $i, Y_{i}$ is the per capita GDP growth for country $i, G_{N I}$ is the gini coefficient for country $i, \operatorname{IND}_{i}$ is the index of the legal independence of each country's central bank. ${ }^{41}$

The variable called independence of the central bank represents the degree of legal independence of central banks. A higher number is associated with a higher degree of legal independence.

The estimates from this extended model are presented in Table $4.3 .{ }^{42}$ As can be seen in Table 3, the estimated coefficient on the index of freedom to use alternative currencies is

\footnotetext{
${ }^{41}$ The average annual inflation rates, trade volumes, and measures of GDP come from the IFS CD-Rom; the per capita GDP growth measures come from the World Economic Outlook; the Gini coefficients are from the Deininger and Squire (1996); and the index of central bank independence is from Cukierman (1992). All variables are an average over the entire time period 1970-1999. However, the gini coefficient is the value for a single year in the mid-eighties as it can be reasonably assumed that the gini coefficient has stayed virtually identical over the period for the OECD countries under study. Similarly, the variable called independence of the central bank represents the degree of legal independence of central banks during the period (1980-89).

${ }^{42}$ Turkey, Poland, Japan, Iceland, and Portugal were removed from the sample because of the lack of data.
} 
negative and significant at the $5 \%$ level. ${ }^{43}$ This result implies that foreign currency competition results in less inflation.

Table 4.3: Determinants of the Average Inflation Rates for
OECD Countries (1970-1999)

\begin{tabular}{|l|cc|}
\hline & {$[1]$} & {$[2]$} \\
\hline Constant & $34.46^{* \prime \prime}$ & 2.83 \\
& $(3.84)$ & $(0.26)$ \\
Freedom to Use Alternative Currencies & $-2.96^{* *}$ & $-1.61^{* *}$ \\
Budget Deficit (Share of GDP) & $(2.60)$ & $(2.59)$ \\
& & 0.02 \\
Trade Volume (Share of GDP) & & $(1.46)$ \\
& & 0.04 \\
Per Capita GDP Growth & & $(1.36)$ \\
& & -300.96 \\
Independence of Central Bank & & $(1.54)$ \\
& & -7.01 \\
Gini Coefficient & & $(0.94)$ \\
& & $0.87^{* * *}$ \\
\hline R-Squared & & $(4.57)$ \\
Number of Observation & & 0.66 \\
\hline
\end{tabular}

Notes: Absolute t-ratios in parenthesis

Significance levels are represented by: ${ }^{* * *} 1 \%,{ }^{* *} 5 \%,{ }^{*} 10 \%$

The variable called freedom to use alternative currency decreases toward zero as the freedom to hold alternative currency decreases. The variable called Independence of Central Bank gets larger as the legal independence of the central Bank is greater.

\subsection{Conclusion}

Understanding the fundamental variables that influence inflation can help policy makers become better prepared to design credible policies. From an empirical standpoint, my

\footnotetext{
${ }^{43}$ In order to stay consistent with the countries analyzed graphically and avoid any suspicion that Mexico could be driving the previous results I run the regression without Mexico. I found that the index of freedom to hold alternative currency is negative and significant at the $1 \%$ level.
} 
results suggest that an increase in the degree of currency competition is associated with a decrease in inflation. In other words, a government that permits foreign or domestic currency competition is forcing its monetary authority to achieve lower rates of inflation, providing a sound environment for economic growth.

My findings have strong implications for Eastern European countries (in particular Hungary, Romania and the Slovak Republic, which have a low degree of freedom to hold alternative currencies) that want to join the European Union and are required to lower their inflation rates. My results suggest that it might be advantageous to associate their central banking reform effort with an increase in the level of permitted domestic currency competition. Currency competition will discipline these central banks and will result in reducing inflation rates.

Stevens (2002) notes that modern electronic money issuers have caused a resurgence in the academic debate about competitive private issuers of currency. ${ }^{44}$ In light of these growing financial innovations, Alan Greenspan (1997) is concerned about the role that the government should play in the "new private currency market of the $21^{\text {st }}$ century." He urges the government not to inhibit the potential of innovation by imposing regulations, and also, emphasizes that the U.S. optimum financial system is one of free and broad competition. My results provide evidence that this increased competition is beneficial and should not be restrained.

\footnotetext{
${ }^{44}$ For example, issuers of electronic money, such as stored-value cards and network money, are private providers of substitutes of U.S. government currency.
} 


\section{Chapter 5 \\ Importing Credible Monetary Policy: A Way for Transition Economies to Fight Inflation?}

\subsection{Introduction}

The fall of the Berlin Wall in 1989 and the rise of independence movements in the Baltics and other Soviet republics led to the implosion of the USSR in December 1991. The USSR's implosion was followed by the birth of a multitude of self-governing states. These newly-freed, and self-governing, states are referred to as transition economies because they are transitioning from centrally-planned economies to market-based economies. Following their independence, almost all of the transition economies created their own national currency and established a central bank to enact a national monetary policy. As mentioned by Schuler (1996), the conventional view among monetary economists, at the time of the formation of the transition economies, was that every independent country should have its own central bank in order to conduct an independent monetary policy.

Ironically, around the same time of the independence movement, the leaders of eleven Western European countries were signing the Maastricht Treaty, which called for the creation of a single European currency and a common European Central Bank. The European Central Bank was created to implement one single monetary policy for all members of the European Monetary Union. This new central bank is completely independent of any political influence and has the overriding role to achieve price stability in the Euroland. ${ }^{45}$

\footnotetext{
${ }^{45}$ Euroland is conventionally used to refer to the area governed by the European Central Bank, which includes the area of its member nations.
} 
The fact that eleven countries gave up their monetary sovereignty to the European Central Bank has created a surge in the academic literature on self-directed monetary policy. Some economists, such as Feldstein (2000), speculate that the loss of monetary autonomy would hurt the economies of the member nations by not allowing them to optimally respond to asymmetric shocks. Other economists such as Fratianni and von Hagen (1993) argue that the commitments to price stability, which some countries were lacking prior to the union, could contribute to a better monetary policy in Europe. According to these authors, the member nations that lacked commitment to price stability would gain credibility by adopting the new monetary institution. In other words, the highinflation countries could use the European Monetary Union as a means to achieve reduced inflationary pressures.

Historically, most countries in transition have faced extreme difficulty in maintaining price stability. The most predominant explanation, as supported by Sachs (1997), is that the transition economies have heightened need for increased government expenditures, which has put pressure on their monetary authorities to print more money. In other words, the fiscal imbalances, which are caused by the inability of the newlycreated governments to collect sufficient revenue, puts pressure on the central banks to collect seigniorage revenue. As noted by Sachs (1997) the resulting high inflation rates can primarily be attributed to the rapid increase in the money supply.

The aim of this paper is to test if the transition economies have better inflation performance when they import the monetary policy of a long-standing, and credible, central bank. For example, I test to see if transition economies that adopt a currency board, experience more stable and/or lower levels of inflation than the transitional 
economies that use a more discretionary monetary policy. I also test to see if transition economies that are on the fast track to join the European union experience lower levels of inflation than the other transition economies. Clearly the real heart of the issue revolves around the degree of discretionary policy that the transition economies have. I propose that those transition economies that limit their ability to use discretionary policy will fare better in their attempts to control inflation.

This paper proceeds by first presenting a brief survey of the different types of institutions that are in effect in the existing transition economies. ${ }^{46}$ In particular, I will characterize currency board institutions and review the literature on the possible effects they could have on the economic performance of transition countries. Next, I examine the relationship between inflation and economic growth in the transition economies to evaluate if a macro policy that aims at reducing inflation provides a better environment for economic growth in those countries. I then proceed to compare the economic performance of twenty-six transition economies by measuring the mean and variance of their inflation rates across the period 1995-2001. This analysis will compare and contrast the performance of transition economies that have adopted a currency board to those using a traditional central-banking system. Finally, I present a cross-sectional analysis showing the effect that adopting a currency board and/or being on the 'fast track' to join the European Monetary Union has on the level of inflation in transition economies. ${ }^{47}$

\footnotetext{
${ }^{46}$ The IMF classifies the following countries as being transition economies: Albania, Armenia, Azerbaijan, Belarus, Bosnia and Herzegovina, Bulgaria, Czech Republic, Croatia, Estonia, Georgia, Hungary, Kazakhstan, Kyrgyz Republic, Latvia, Lithuania, Macedonia, Moldova, Mongolia, Poland, Romania, Russia, Slovak Republic, Slovenia, Tajikistan, Turkmenistan, Ukraine, Uzbekistan, and Yugoslavia.

${ }^{47}$ I refer to countries being on the 'fast track' to join the European Monetary Union as those countries that are invited to join the European Union as early as 2004.
} 


\subsection{Central Banks versus Currency Boards}

According to public choice theory, an institution's performance is conditional on the incentives that the individuals within the institution face. For example, Friedman (1982) emphasizes the importance of looking at the incentives that monetary policy makers face. According to Friedman, the forces that control the behavior of the policy maker are not necessarily in-line with the social welfare function of the monetary institution. For example, a central banker with more discretion in implementing monetary policy could better achieve economic stability. However, studies by Toma (1982), and Shughart and Tollison (1983) found that the lack of constraints on central bankers result in an overproduction of money beyond the optimal welfare level, which could hurt the economy. Therefore, the lack of constraints on central bankers, which allow them to enjoy more discretion in implementing monetary policy, could result in a less (rather than a more) stable economy.

When the transition economies seceded from the former Soviet Union, the new independent governments' revenue requirements were substantial. Sachs (1997) analyzes in detail why Poland, as did many of its neighbors, experienced a higher budget deficit while transitioning to the market-based economy. Aizenman (1987) suggests that greater government demand for revenue will increase the use of inflation as a revenue-generating device. Clearly, the choice of the monetary institution, which affects the discretionary ability of the transition-economy policy makers, is an important determinant in the overall performance of the monetary authority's ability to control inflation. More specifically, the institutions that limit the monetary authority's incentive to cater to the revenue-generating pressures will produce a better outcome in controlling inflation. 
Most of the transition economies chose to implement a sovereign central bank as their monetary institution. The traditional socialist monobank system, which had no distinction between central banks and state-owned commercial banks, was transformed to a two tier banking system with a sovereign central bank and a separate commercial banking system. The new central banks use discretionary monetary policy and, according to Cukierman, Miller, and Neyapti (2000), have a significant degree of legal independence from the government. The designed independence of the central banks shows that the governments of the transition economies had good intentions to protect the new central banks from political and budgetary pressures. Nevertheless, as stated by Toma (2001), the independence that governments attribute to central banks does not create enough constraints for the policy maker to effectively enact policies in the interest of the general public. Toma's observation would imply that the independence granted to the transition economies' monetary institutions is not enough to prevent policy makers from rapidly increasing the money supply.

In an attempt to further reduce the influence of political motives in the money supply process, some governments chose to restrict their discretionary use of monetary policy by adopting another form of monetary institution - a currency board. This alternative form of monetary institution was adopted by four of the transition economies (Estonia, Lithuania, Bulgaria, and Bosnia and Herzegovina). Currency boards effectively tie the hands of the monetary authorities by inhibiting the fiduciary issue of their currency, as the backing of the currency must be at least $100 \%$. More specifically, a currency board is required to exchange domestic currency for foreign reserve currency at a specified and fixed rate. To perform this function the board is required to hold financial 
assets in the foreign reserve currency at least equal to the value of the domestic currency outstanding. Another characteristic of a currency board (unlike a central bank) is that it cannot function as a "lender of last resort" to the state treasury or commercial banks, implying that the board cannot monetize the government's budgetary deficits.

At the time that the transition economies were deciding on what monetary institutions to adopt, the International Monetary Fund dismissed the currency board idea. In particular, Nenovsky (2001) documents the skepticism of the IMF during Estonia and Bulgaria's early attempts to adopt the currency board institution. The IMF's initial rejection of currency boards was based on the notion that the currency boards would not allow flexibility in offsetting country-specific shocks, which would eventually lead to the deterioration of their economic performance. Moreover, the traditional central bank institution just seemed to fit better with the mainstream ideology of the IMF's senior economists.

However, the IMF position was relaxed by the findings of Gosh, Gulde, and Wolf (1998, 2000), all economists at the IMF, which show that countries with currency boards enjoy lower inflation levels, as well as higher output growth relative to countries with self-governing central banks. Recently, many other economists have been analyzing the economic performance of countries under currency boards. In particular, one of the latest event study by Hanke (2002) found compelling evidence supporting the notion that transition economies that adopt currency boards experience improved economic performance.

However, all economists do not agree on the benefits from adopting a currency board. In particular, some economists, such as Nouriel Roubini (1998), believe that 
currency boards are "weak" institutions with very mixed economic outcomes. Therefore, the debate is still on going, and the following sections will attempt to shed some light on the economic performances of transition economies with currency boards.

\subsection{Economic Performances in Transition Economies.}

The academic literature such as Fisher (1993), and Motley (1994) tends to find a negative relationship between inflation rates and economic growth. The first question that is raised in this section is whether or not this relationship holds for the transition economies. More specifically, are lower levels of inflation associated with higher output growth in the transition economies?

Figure 5.1: Average Annual Inflation and GDP Growth (1995-2001)

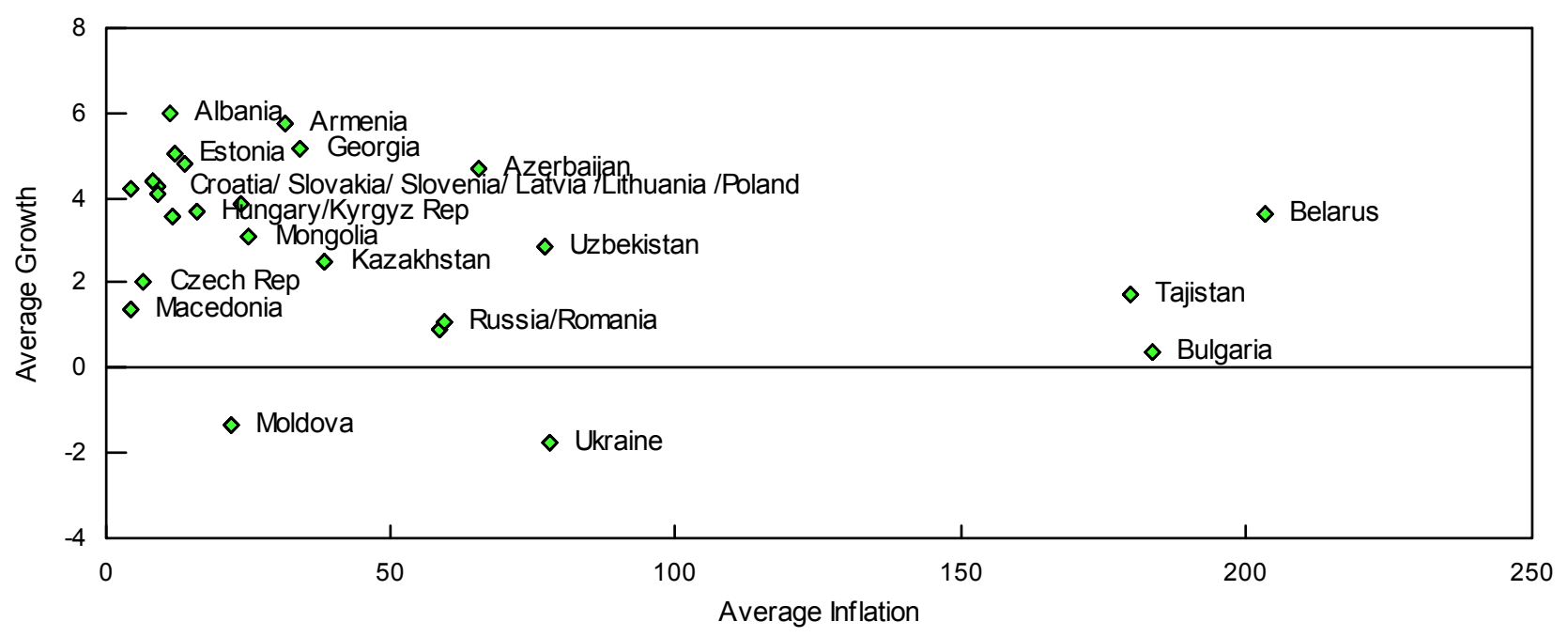

A simple analysis of the inflation and output growth performances of the transition economies is performed to try and answer this question. Specifically, I analyze the relationship between each transition economy's average annual inflation rate with their average annual GDP growth rate, from 1995-2001. The results of this analysis are 
presented in the scatter plot diagram illustrated in Figure 5.1. The scatter plot diagram shows that the inverse relationship between inflation and GDP growth exists in the transition economies. Therefore, any macroeconomic policy that encourages lower levels of inflation is likely to promote economic growth in the transition economies.

Next, my analysis will focus on determining which type of monetary institution is best for achieving low and stable inflation rates. Hanke and Schuler $(1992,1994)$ argue that the nations that are trying to become market economies are placing too much of the responsibility on the central bank. According to the authors, in order for transition economies to issue a fiat currency that retains its purchasing power (value), the central banks need to be credible and effectively control domestic prices. After the collapse of the Soviet Union, and the distrust of the Ruble, none of the transition economies' central banks seemed to possess the required credibility to supply a sound and valuable currency. Generally, the newly created national central banks had yet to acquire a credible reputation of following low-inflation policies, and the public perception of these central banks was that they would inevitably fail at producing low and stable rates of inflation.

Previous papers, such as Hanke (2002), look at the economic performance of various countries around the globe that have switched from a central bank to a currency board, and find that their economic performance improved after the switch. The contribution of my paper is that it is the first to explicitly focus on all the transition countries and statistically compare their performances in maintaining stable and low inflation rates with the structure of their monetary institutions. My objective is to examine whether or not transition countries with currency boards offer sounder money, in other words lower inflation, than transition countries with central banks. 
To perform this analysis I compute the average annual inflation rates and inflation variances for twenty-six transition economies. Then, my analysis proceeds by statistically comparing the inflation variances of transition economies with currency boards to the inflation variances of transition economies operating under a central bank system. Finally, I perform the same comparisons using the average annual inflation rates of the two groups of transition economies. Table 5.1 presents the variance of inflation rates, as well as, the average annual inflation rates of twenty-six transition economies for which data were available for the time period, $1995-2001 .^{48}$ The transition economies with currency boards are highlighted in bold print, and if the switch from central bank to currency board occurred during the sample period the data for both periods are separately reported.

The last rows of Table 5.1 present comparisons of central bank and currency board institutions by averaging the inflation measures of the transition countries with central banks and the transition countries with currency boards. The difference in the average inflation variances under the two monetary institutions, measured as the variance of inflation under central banking minus the variance of inflation under currency boards, is positive. This result implies that inflation under central banking is more volatile than inflation under currency board. In other words, currency boards produce more stable inflation rates than central banking regimes.

\footnotetext{
48 The data come from the IMF and are available for twenty-six transition economies. Variance and average inflation rates are taken from the period 1995-2001. In 1995, Estonia and Lithuania were already under a currency board system. Bulgaria and Bosnia and Herzegovina abandoned the central banking system in the summer of 1997. For those countries central bank observations go from 1995-1996, and currency board observations go from 1998-2001. The year 1997 was unclassifiable to either of the categories due to the annual data availability.
} 
Table 5.1:Comparing Inflation Variances and Average Annual Inflation Rates for 26 Transition Countries (1995-2001)

\begin{tabular}{|c|c|c|}
\hline Transition Countries & Variance of Inflation & Average Annual Inflation \\
\hline Albania & 136.04 & 11.25 \\
\hline Armenia & 4142.40 & 31.63 \\
\hline Azerbaijan & 27589.12 & 65.61 \\
\hline Belarus & 57435.39 & 203.30 \\
\hline Bosnia & $96.61(3.86)$ & $-6.75(3.12)$ \\
\hline Bulgaria & $1770.13(46.16)$ & $91.85(9.82)$ \\
\hline Croatia & 2.06 & 4.29 \\
\hline Czech Republic & 10.38 & 6.83 \\
\hline Estonia & 101.03 & 12.07 \\
\hline Georgia & 3370.77 & 34.34 \\
\hline Hungary & 56.02 & 16.20 \\
\hline Kazakhstan & 3810.15 & 38.59 \\
\hline Kyrgyz Republic & 156.14 & 24.03 \\
\hline Latvia & 79.41 & 9.01 \\
\hline Lithuania & 222.53 & 11.60 \\
\hline Macedonia & 31.47 & 4.36 \\
\hline Moldova & 152.10 & 21.94 \\
\hline Mongolia & 438.06 & 25.29 \\
\hline Poland & 61.28 & 13.90 \\
\hline Romania & 1874.90 & 58.71 \\
\hline Russia & 4336.37 & 59.37 \\
\hline Slovakia & 6.11 & 8.36 \\
\hline Slovenia & 5.20 & 9.03 \\
\hline Tajikistan & 55617.62 & 179.77 \\
\hline Ukraine & 17890.12 & 78.00 \\
\hline Uzbekistan & 10358.39 & 77.11 \\
\hline $\begin{array}{l}\text { Countries under Currency Board } \\
\text { Institution } \\
\text { Countries under Central Bank }\end{array}$ & 93.40 & 9.16 \\
\hline Institution & 7892.76 & 44.42 \\
\hline Central Bank - Currency Board & $7799.36^{\star * *}$ & $35.26^{*}$ \\
\hline Statistical Difference Test & $F=84.51$ & $t=1.88$ \\
\hline
\end{tabular}

Notes: Significance levels represented by: ${ }^{* * *} 1 \%,{ }^{* *} 5 \%,{ }^{*} 10 \%$
Transition economies with currency boards are in bold and italic print. For those countries that switched from central bank to currency board, their measures are presented in the following manner: central bank measure (currency board measure), so that comparisons can be made.

In order to check the significance of the findings, a difference in variance test is performed, which includes the following null (that implies the variances are not statistically different) and alternative hypothesis to be tested: 


$$
\begin{aligned}
& \mathrm{H}_{0}: \sigma^{2}{ }_{1}=\sigma^{2}{ }_{2} \\
& \mathrm{H}_{\mathrm{A}}: \sigma^{2}{ }_{1} \neq \sigma^{2}{ }_{2}
\end{aligned}
$$

Where $\sigma^{2}$ is the average variance of inflation in the transition economies with a currency board system, and $\sigma_{2}^{2}$ is the average variance of inflation in the transitional economies under a central-banking system. I use a standard two-tailed F-test where the computed Fstatistic follows the following calculation:

$$
F_{T}=\frac{\sigma_{2}^{2}}{\sigma_{1}^{2}}
$$

I can reject the null hypothesis of equal variances at the one-percent level of confidence. Therefore, I find that inflation is significantly more stable in countries with currency boards than in countries with central banking systems. This result is in accord with Hanke and Schuler's (1994) claim that central banks will not produce stable currencies in the transition economies.

The difference in the annual average inflation of under the two monetary institutions, measured as the average inflation under central banking minus the average inflation under currency boards, is also positive. This result implies that inflation under central banking is higher than inflation under currency board. In other words, currency boards produce lower inflation rates than central banking regimes.

In order to check the significance of this finding, a difference in mean test was performed, which included the following null (that implies the average inflation rates under a currency board system is lower than the average inflation rate under a central bank system) and alternative hypothesis to be tested: 


$$
\begin{aligned}
& \mathrm{H}_{0}: \mu_{1}=\mu_{2} \\
& \mathrm{H}_{\mathrm{A}}: \mu_{1}<\mu_{2}
\end{aligned}
$$

Where $\mu_{1}$ is the average annual inflation rate under currency board system, and $\mu_{2}$ is the average annual inflation rate under central banking. I use a standard one-tailed t-test where the computed t-statistic follows the following calculation:

$$
\begin{gathered}
\mathrm{t}_{\text {computed }}=\frac{\mu_{1}-\mu_{2}}{\sqrt{ }\left(\sigma^{2}{ }_{1} / \mathrm{n}_{1}\right)+\left(\sigma^{2}{ }_{2} / \mathrm{n}_{2}\right)} \\
\mathrm{df}=\frac{\left[\left(\sigma^{2}{ }_{1} / \mathrm{n}_{1}\right)+\left(\sigma^{2}{ }_{2} / \mathrm{n}_{2}\right)\right]^{2}}{\left(\left(\sigma^{2}{ }_{1} / \mathrm{n}_{1}\right)^{2} /\left(\mathrm{n}_{1}-1\right)\right)+\left(\left(\sigma^{2}{ }_{2} / \mathrm{n}_{2}\right)^{2} /\left(\mathrm{n}_{2}-1\right)\right)}
\end{gathered}
$$

where $n_{1}$ is the number of countries with currency boards, $n_{2}$ is the number of countries with central banks; and $\sigma_{1}$ and $\sigma_{2}$ are the inflation rate variances for countries under a currency board and a central-banking system respectively. The degree of freedom (df) is measured as indicated above. The null hypothesis of equal average annual inflation rates was rejected at the $5 \%$ significance level. Therefore, I find that inflation is significantly lower in countries with currency boards than in countries with central banking systems.

In summary, my results show that transitional economies operating under a currency board system experience lower and more stable inflation than their counterparts experience under a central banking system. My findings conform the results that Hanke (2002) reports for the developing countries. Also my results support the findings of Hanke and Schuler (1992), which argue that countries gain substantial credibility by adopting a currency board, where the gain in credibility is exemplified by a sounder money (a lower, and more stable inflation rate). 


\subsection{Cross-National Analysis of the Determinants of Inflation in Transition Countries}

In this section I analyze the determinants of inflation in transition economies. Particularly, extending the analysis from the previous section I will investigate the relationship between adopting a currency board and inflation rates. In addition, I will look at the effects of other discretionary policy restraints on inflation rates. Although my current study would be improved by cross-national time series data the severe limitation of reliable data for the transition countries limited me to do the study just for the year 2002.

The empirical model that I use to investigate the determinants of inflation is original as it introduces the effect of adopting a currency board, as well as the effect of being on the fast track to join the European Union. I use the term fast track to refer to transition countries that are invited to join the European Union as early as 2004. In this analysis, transition economies could be classified into four different groups: (i) transition economies with only a currency board, (ii) transition economies only on the fast track to join the European Union, (iii) transition economies with both a currency board and on the fast track to join the European Union, and (iv) Transition economies with no currency board and not on the fast track to join the European Union. ${ }^{49}$ I hypothesize that the

\footnotetext{
${ }^{49}$ In 1999, the fifteen members states of the European Union announced that eight transition countries: Poland, Hungary, Estonia, Lithuania, Slovenia, Slovak Republic, Czech Republic, and Latvia will be able to join the Union in 2004. In December 2002, member states of the European Union gathered in Copenhagen, to begin the biggest enlargement of the European Union. There, the eight countries from the former Eastern Soviet bloc were officially invited to join the European Union in 2004. In April 2003, in Athens, the eight new members signed the Treaty of Accession to the European Union. After ratification of the treaty, the ten new members will join the existing fifteen on May 1st, 2004, to form a cohesive partnership in a twenty-five-nation group. Those eight countries are referred to as being on the fast track to join the European Union. Among those eight countries, Lithuania and Estonia have also adopted a currency
} 
transition economies adopting a currency board, being on the fast track to join the European Union, or having both characteristics, will experience more discipline on their fiscal authorities and also will bring more credibility to the domestic currency resulting in lower rates of inflation.

The rationale for estimating the effect of being on the 'fast track' to join the European Monetary Union rests on the assumption that many of the changes that promote economic growth require changes in institutions such as, for example, replacing a central bank by a currency board; however, it could just be a change in the self-discipline of the government, without any change in institutions that could lead to such growth. For example, Rogoff (1985) shows how a "conservative" central banker, or movement to stronger self discipline by primarily and explicitly targeting inflation, can provide the credibility needed for the monetary institution to implement effective policies that lead to lower inflation and more economic growth. Hanke and Schuler (1994) underline the "upright character" of the Czech finance minister, Vaclav Klaus, which helped maintain inflation rates in his country that were significantly lower than those experienced by the other transition economies. I propose that the commitment of a transition economy to a transition into the European Union will produce credibility, as well as disciplinary gains through the "acquis communautaires" set forth by the European Union. ${ }^{50}$

board system. The remaining six countries on the fast track to join the European Union have chosen to stay under a central banking system. The other nineteen transition countries are not on the fast track to join the European Union. Among those countries, not on the fast track to join the European Union, only Bulgaria and Bosnia and Herzegovina have chosen to adopt a currency board system all others have chosen a central banking system.

${ }^{50}$ The 'acquis communautaires' set forth by the European Union include stability of institutions; the existence of a functioning market economy; the ability to take on the obligations of membership including adherence to the aims of political, economic and monetary union. 
To examine the determinants of inflation I estimate a regression that takes the following form: ${ }^{51}$

$$
\text { Inflation }=f(\mathrm{CB}, \mathrm{EURO}, \mathrm{BOTH}, \mathrm{X})
$$

Where CB is a dummy equal to 1 for countries that only have a currency board (so it excludes those with both a currency board and a commitment to be on the fast track to join the European Union), and equal to 0 otherwise. Similarly, the EURO is a dummy equal to 1 for countries only on the fast track to join the European Union (so it excludes countries that have both a commitment to be on the fast track to join the European Union and a currency board), and equal to 0 otherwise. BOTH is a dummy equal to 1 for countries that have both a currency board and a commitment to be on the fast track to join the European Union, and equal to 0 for all other countries. ${ }^{52}$

$X$ is a vector of control variables that closely conforms to what has been previously used in the literature. Generally, the control variables include fiscal, economic, and structural influences on inflation. The fiscal influence is measured as the government fiscal balance as a percentage of GDP (Deficit Share of GDP). ${ }^{53}$ This

\footnotetext{
${ }^{51}$ All data are from the CIA World Fact Book of 2002 unless stated otherwise. The 22 countries under study are Armenia, Azerbaijan, Belarus, Bulgaria, Croatia, Czech Republic, Estonia, Georgia, Hungary, Kazakhstan, Kyrgyz Republic, Latvia, Lithuania, Moldova, Mongolia, Poland, Romania, Russia, Slovenia, Slovakia, Ukraine, and Uzbekistan.

${ }^{52}$ The choice of the monetary regime in my regression is taken as exogenous. I would like to acknowledge the argument that my regression could face a simultaneity bias. Indeed, economists have argued that certain economic preconditions such as strong and well-managed financial system, adequate reserves, and fiscal discipline needed to be satisfied before a currency board could be to be adopted. Hanke (2000) empirically refutes this argument. However, I will address this argument in an appendix checking on the robustness of my results.

${ }^{53}$ I also run the same regression using external debt as a share of GDP as a measure of the fiscal motives that could drive inflationary pressures. Results using the amount of external debt as a share of GDP produce even stronger results for the dummies of interest.
} 
variable is expected to carry a positive sign because of the assumption that fiscal motives drive inflation pressures, particularly in transition economies. I include several economic influences that are traditionally used to explain inflation rates. These variables include the annual GDP growth rate (GDP Growth), openness as measured by a country's imports plus exports as a percentage of GDP (Trade Volume Share of GDP), and the Gini coefficient as a measure of income inequality. Also, following the work of Cukierman, Miller and Neyapti (2000) I include the index of legal central bank independence (Independence of Central Bank) and the cumulative liberalization index (Liberalization) as control variables. ${ }^{54}$ It is also possible that countries with lower inflation have a geographical, political, and cultural closeness to different region of the world. To control for the cultural, political, and geographical impact on inflation I include a dummy variable (Regional Dummy) equal to 1 if the country is located in the central and eastern European region, and equal to 0 if the country belongs to the Commonwealth of the Independent States and Mongolia. This control has been added following the IMF regional classification of transition economies. The estimated determinants of inflation from this model are presented in Table 5.2.

The estimated coefficient on the Currency Board dummy is negative and statistically significant at the 5\% level. This result implies that countries that adopt a currency board system, and not on the fast track to join the European Union, experience significantly less inflation relative to countries that have the traditional central banking

\footnotetext{
${ }^{54}$ Both indices are from of Cukierman, Miller and Neyapti (2000) paper. The liberalization index measures the extent of liberalization of domestic prices and abolition of state trading monopolies. It also measures the degree of liberalization of the foreign trade regime, which includes the extent of currency convertibility, and the extent of enterprise privatization and banking reform.
} 
system and not on the fast track to join the European Union. Again the rationale is that the currency board institution constrains the government prevent it from overissuing its currency. More specifically, a currency board constrains the ability to use discretionary policies to debt finance through inflation taxes.

Table 5.2: Determinants of the Inflation Rates for Transition Countries in 2001

\begin{tabular}{|l|c|}
\hline Independent Variables & $50.61^{* * *}$ \\
\hline Constant & $(2.95)$ \\
Currency Board & $-21.01^{* *}$ \\
Fast Track to Join Euro & $(2.43)$ \\
& $-13.78^{*}$ \\
Both Currency Board \& Fast Track to Join Euro & $(2.12)$ \\
& $-23.59^{\star *}$ \\
Budget Deficit (Share of GDP) & $(2.39)$ \\
& $8.25^{*}$ \\
Trade Volume (Share of GDP) & $(1.75)$ \\
GDP Growth & 0.02 \\
& $(0.77)$ \\
Independence of Central Bank & $-1.87^{* *}$ \\
& $(2.16)$ \\
Liberalization & 4.44 \\
& $(0.37)$ \\
Regional Dummy & $-5.74^{*}$ \\
Gini Coefficient & $(1.96)$ \\
\hline R-Squared & $15.99^{* *}$ \\
Number of Observation & $(2.18)$ \\
\hline
\end{tabular}

Notes: Absolute t-ratios in parenthesis

Significance levels are represented by: ${ }^{* * *} 1 \%,{ }^{* *} 5 \%,{ }^{*} 10 \%$

The estimated coefficient on the Fast Track to Join the European Union dummy is negative and statistically significant at the 5\% level. This result implies that countries that are on the fast track to join the European Union, but have not adopted a currency board, experience significantly less inflation relative to countries that have the traditional central banking system and not on the fast track to join the European Union. Again the rationale is that publicly committing to join the European Union reduces the flexibility of the 
monetary authorities in overissuing money. The BOTH coefficient also carried a negative sign with a significance of $5 \%$ showing that countries with both a change in the institution and a commitment to join the European Union experience lower rates of inflation. The fiscal deficit carried the expected statistically significant positive sign showing that fiscal motives increase inflationary pressures in the transition economies. Also, it is interesting to notice that high degrees of liberalization in transition economies significantly lower the inflation rate. This result reinforces the finding of Melo, Denizer, and Gelb (1996). More specifically by abolishing state trading monopolies, allowing domestic currency convertibility, as well as increasing the extent of enterprise privatization and banking reform limit the pressure that monetary authorities receive from politicians, and give the monetary authorities more incentive to provide a more valuable currency and achieve lower levels of inflation.

As showed in table 5.2, the estimated coefficients on the CB dummy, EURO dummy, and BOTH dummy are negative and statistically significant. I perform a statistical test to analyze the equality of the two regression coefficients-- being on the fast track to join the European Union or adopting a currency board. The test includes the following null (that implies that having a currency board or being on the fast track to join the European Union are not statistically different) and alternative hypothesis to be tested:

$$
\begin{aligned}
& \mathrm{H}_{0}: \beta_{1}=\beta_{2} \\
& \mathrm{H}_{\mathrm{A}}: \beta_{1} \neq \beta_{2}
\end{aligned}
$$

Where $\beta_{1}$ is the estimated coefficient of having a currency board system, and $\beta_{2}$ is the estimated coefficient of being on the fast track to join the European Union. I use a standard t-test where the computed t-statistic follows the following calculation: 


$$
\mathrm{t}_{\text {computed }}=\frac{\left(\hat{\beta_{1}}-\hat{\beta_{2}}\right)-\left(\hat{\left.\beta_{1}-\beta_{2}\right)}\right.}{\operatorname{se}\left(\hat{\beta_{1}}-\hat{\beta_{2}}\right)}
$$

where se $\left(\hat{\beta_{1}}-\hat{\beta_{2}}\right)$ is the standard error of the estimated parameters. The null hypothesis of equal regression coefficients could not be rejected. Therefore, I find that the impact of having a currency board or being on the fast track to join the European Union on inflation is not statistically different. Similar statistical tests show that having a currency board and being also on the first track to join the European Union has the same impact on inflation that having only a currency board or only being on the fast track to join the European Union without having a currency board. In summary a country needs only to have a currency board or to be on the fast track to join the European Union in order to achieve lower levels of inflation. However, having both characteristics does not hurt inflation performances. Specifically, countries that are simultaneously under a currency board regime and on the fast track to join the European Union experience lower level of inflation than countries that are neither under a currency board regime nor on the fast track to join the European Union. ${ }^{55}$

\footnotetext{
${ }^{55}$ A regression is also run in order to analyze the effect of having only a currency board, being only on the fast track to join the European Union, or having both characteristics has on inflation variability. The estimated coefficients in front of each of the three dummy variables carried a negative sign, showing that a restraint in the discretionary power to set macro policies would decrease volatility in inflation rates and stabilize the general price level. However, none of the coefficients was significant at the satisfactory $10 \%$ level. This reflects the fact that due to data constraints I could not regress variance of inflation rates on variance of all the other control variables. Similarly, I run another regression to investigate the effect of having only a currency board, being only on the fast track to join the European Union, or having both characteristics has on the average inflation spanning from 1995 to 2001. Results show that being on the fast track to join the EU and having a currency board and being at the same time on the fast track to join the EU have a significant negative effect on average inflation.
} 


\subsection{Conclusion}

Most economists agree on the fact that a country that wants to achieve high and sustainable economic growth needs to maintain low and stable inflation. In the transition countries, where pressures to use the inflation tax to help cover the government's expenditures is strong, the choice of a monetary institution seems to be of utmost importance. In recent years the view that currency boards should be adopted in transition countries to add credibility and alleviate inflationary tendencies has divided economists.

This paper first shows that, in transition economies, lower inflation levels foster greater economic growth. Relying on statistical difference tests, I find that transition economies with currency boards experience more stable and lower rates of inflation relative to transition economies with central banks. These results support Person and Tabellini's (1990) skeptical view about central banks that have tendency to "abuse" their flexibility when implementing monetary policy.

Using a traditional model of inflation I test to see if the transitional economies that have adopted a currency board produce less inflationary bias. I also test to see if the transitional economies that have committed to joining the European Monetary Union effectively import more credible monetary policy through self-discipline, and thus lower their inflation rates. I find across all specifications that adopting a currency board is an effective way to achieve lower levels of inflation. It is also interesting to note that transition countries being on the fast track to join the European Monetary Union experience lower inflations rates relative to those countries that are not on the fast track. Generally, in committing to join the European Monetary Union, the government imposes constraints on itself that limit discretionary use of its macroeconomic policy tools. 
This paper strongly advocates in favor of changes in monetary institutions in transition economies. Transition economies should replace their existing central banking regime by a currency board regime that would impose monetary discipline by restricting monetary authorities' discretionary powers. In other words, my findings show that the transition economies will 'import' credible monetary policy by adopting currency boards, lower their inflation level, and therefore increase their economic growth.

It is also possible that by committing to meeting the 'acquis communautaires' of the European Union, of which maintaining low inflation rates and budget deficits are expected, could be an effective way to achieve lower levels of inflation. Strong and visible commitments of policy makers can discipline and bring credibility to the monetary authorities.

This study strengthens the existing literature on the benefits of adopting a currency board. There should be no debate anymore on whether currency board is the appropriate institution to discipline monetary policy and help avoid the expansionary monetary policy bias coming from the politics and facing the monetary authorities of transition economies. This paper also clearly demonstrates that transition economies could achieve lower levels of inflation, by self-disciplining themselves without a change in their monetary institutions, as long as their commitment is real and that they publicly pre-commit to rules and guidelines that do restrain their discretionary power in macro policy. 


\section{Chapter 6 \\ Conclusion and Areas of Future Research}

Recent empirical work suggests that low and stable inflation rates are associated with faster economic growth. Therefore, a monetary authority can promote economic growth by providing a stable monetary environment. The aim of this dissertation has been to make policy suggestions for improving current monetary arrangements consistent with improving monetary stability and economic growth.

Recently, several monetary regimes around the world have begun mandating that the sole goal of their monetary authority is to achieve low and stable price levels. Also, there has been a movement towards ensuring that the existing monetary institutions have an increasing degree of political independence. This trend reflects the theoretical and empirical findings in the monetary economic literature that credible commitments and independent central bankers reduce inflationary bias.

This dissertation contributes to the vast monetary policy literature that analyzes what macroeconomic goals are most appropriate for monetary authorities to target. Also, the research in this dissertation explicitly deals with the degree of discretionary power that is set up by institutional constraints, as well as, the incentives that the central bankers act on, that influence the overall effectiveness of different regimes to provide low and stable inflation rates. The empirical studies that I perform show that the countries experiencing both stable economic performances and low and stable inflation seem to have many characteristics in common. From my empirical findings it is possible to make several policy recommendations that have broad applicability. The remainder of the current chapter will (i) summarize the major findings of each of the three research chapters, (ii) extract the 
recommendations for improving existing monetary arrangements, and (iii) propose suggestions for future research.

Summary 1: Chapter 3 of this dissertation addresses the ongoing debate about the role of active central bank intervention in producing economic stability. The recent formation of the European Monetary Union is seen as a natural experiment, in that member states abandoned their independent monetary policies (whether active or nonactive) in favor of a common (relatively monetarist) policy. The results show that countries find increased economic stability after coming under the relatively inactive (monetarist) European Central Bank. Furthermore, my findings show that the countries experiencing the greatest gains in stability are precisely those whose old national central banks practiced the highest degree of activist stabilization. In other words, the countries that have had the greatest reductions in monetary activism have gained the most in economic stability.

Lesson 1: Activist stabilization policy on the part of central banks, while well intentioned, actually leads to greater economic instability. Therefore, the lesson to be learned is that a less active central bank that is committed to price stability, rather than output stability, results in greater macroeconomic stability.

Suggestion1: Given that the ECB is a relatively infant monetary institution, my analysis could be improved by extending the data set over the years to come to see if the ECB retains its monetarist position. Under the notion that the ECB is designed to rival the U.S. central bank, a comparison of the degree of activism of the two institutions could be relevant in the coming years. Given the early success of the ECB, it is a plausible scenario that the U.S. could try to follow in the monetarist footsteps of the ECB. It would 
be also interesting to see if the findings of this chapter hold up with more data in a few years.

Summary 2: Chapter 4 draws upon Adam's Smith principle that individuals left to pursue their own self-interest will inherently promote the economic well-being of society. Currency issuers want to gain seigniorage revenue by having the largest market share of people holding their currency. Likewise, people want to hold the currency that has the most value. If a currency issuer is faced with less competition (domestic, as well, as international), it will be freer to use its monopolistic power and the result will be detrimental to society. This chapter empirically investigates whether currency competition leads to lower inflation rates. Results show that a country's average inflation rate is higher after it creates a monopolistic central bank. Also, a country's inflation rate is found to be negatively correlated with its "Index of Freedom to Use Alternative Currencies" score. In particular, countries allowing citizens to legally hold foreign currency tend to have lower average rates of inflation. Generally, my results show that currency competition among issuers, either from abroad or within the country's boarders, heightens the incentives for monetary issuers to pursue lower inflation rates and produce a more credible money supply.

Lesson 2: A government that permits foreign, or domestic, currency competition is giving incentive for its monetary authority to achieve lower rates of inflation. In other words, currency competition disciplines central bankers. Specifically, competition among currency suppliers provides consumers with choices offering them the possibility to substitute away from low valued currency to one that would provide them with a higher purchasing power and stronger store of value. Therefore, the lesson to be learned is that 
governments should not inhibit the potential of financial innovations that lead to a wider range of currencies by imposing regulations, and more importantly, currency competition originating from foreign central banks should not be restrained.

Suggestions 2: An easy extension of this analysis would be to find another form of currency competition to investigate and see if it has significant effects on inflation. For example, noticing the current electronic banking phenomenon (such as e-money) investigations might be warranted into the effects that this innovative cash forms have on international currency competition and their effect on inflation rates.

Summary 3: In the early 1990s, transition countries had the opportunity to rearrange their monetary institutions to better achieve low levels of inflation. The transition economies had several prominent monetary arrangements to choose from, such as sovereign central banks or currency boards. This chapter surveys the monetary institutions currently in place in several transition economies and compares them based on their ability to control inflation. I investigate to see if transition economies that adopt a currency board, experience more stable and/or lower levels of inflation than the transitional economies that use a more discretionary monetary policy. I also test to see if transition economies that are on the fast track to join the European union experience lower levels of inflation than the other transition economies. Clearly the heart of the issue revolves around the degree of discretionary policy that the transition economies have. My results show that the transition economies that limit their ability to use discretionary policy perform better in controlling inflation.

Lesson 3: Currency Boards, as well as, public commitment to join the European Union provide a constraint on monetary authorities of transition economies by giving 
them the necessary discipline to achieve economic growth. This is not saying that the monetary authorities do not attempt to maneuver around the constraints and introduce some discretion when implementing their policies. However, as long as the potential benefits received by an individual policymaker from a monetary expansion are smaller that the political costs of deviating from their commitments, temptation to inflate will be annihilated. Therefore, the lesson to be learned is that limiting discretionary powers in implementing monetary policies creates lower and more stable levels of inflation in transition countries.

Suggestion 3: Clearly, further analysis of the economic and monetary performance of the transition economies is warranted leading up to their inclusion into the EU, and thereafter. Also, it would be worthwhile to investigate which countries on the fast track to join the EU, if any, proceed to becoming a part of the EMU. 


\section{Appendix A}

Table A.1 reports the Taylor Rule estimates for each county's national central bank prior to the formation of the ECB. The standard errors are given in parentheses and are constructed using the delta method.

Table A.1: Results of the Taylor Rule Regressions:

\begin{tabular}{|l|ccccc|}
\hline Country & $\alpha$ & $\beta$ & $V$ & $\rho$ & $\mathrm{R}^{2}$ \\
\hline Germany & 1.83 & 1.69 & 0.05 & 0.83 & 0.99 \\
& $(0.95)$ & $(0.32)$ & $(0.12)$ & $(0.07)$ & \\
Austria & 1.01 & 1.75 & 0.16 & 0.79 & 0.96 \\
& $(1.08)$ & $(0.31)$ & $(0.12)$ & $(0.06)$ & \\
Belgium & 3.87 & 1.06 & 0.14 & 0.76 & 0.86 \\
& $(0.53)$ & $(0.13)$ & $(0.08)$ & $(0.04)$ & \\
Spain & 7.22 & 0.75 & 0.19 & 0.83 & 0.82 \\
& $(0.86)$ & $(0.10)$ & $(0.11)$ & $(0.02)$ & \\
France & 4.61 & 0.97 & 0.34 & 0.93 & 0.96 \\
& $(1.72)$ & $(0.29)$ & $(0.42)$ & $(0.03)$ & \\
Italy & & & & & \\
& 5.07 & 0.99 & 0.45 & 0.96 & 0.98 \\
& $(3.90)$ & $(0.43)$ & $(0.78)$ & $(0.03)$ & \\
\hline
\end{tabular}

Notes: Standard errors are given in parentheses.

A number of interesting results stand out that allow me to point to difference monetary policy reaction function across countries. The estimates of $\beta$, the coefficient associated with expected inflation, are significantly above one for the three countries, Germany, Belgium, and Austria. Also, the estimates of $\gamma$, the coefficient measuring the sensitivity of the central bank to the output gap variable, are the lowest for those three countries. This king of monetary policy reaction function indicates that the central bank of those three countries is targeting inflation more heavily than the output gap. Therefore, 
Germany, Belgium, and Austria are classified as less active national central bank relative to the central banks of France, Italy, and Spain. The estimates for the interest smoothing parameter $\rho$ are quite high in all cases showing the conventional knowledge that central banks smooth adjustment in the interest rate. 


\section{Appendix B}

Results in Chapter 3 show that average inflation rates are significantly lower during periods of free-banking regimes when compared to average inflation rates during centralbanking regimes in nine selected OECD countries.

This appendix presents empirical analysis that is used to investigate whether the variance of inflation is different under free-banking regimes and central-banking regimes. Specifically, a difference of variance test is performed. My objective is to examine whether or not central-banking regimes offer less variance in inflation, or in other words less inflation volatility, than free-banking regimes.

To perform this analysis I compute the inflation variances for the same nine OECD countries. Then, I statistically compare the inflation variances during free-banking regimes to the inflation variances under central-banking regimes. Table B.1 presents the variance of inflation for the nine OECD countries, for which data were available for the time period.

The difference in the inflation variances under the two monetary regimes, which is measured as the variance of inflation under free-banking regimes minus the variance of inflation under central-banking regimes is significantly negative for four countries. This result implies that inflation under central banking is more volatile than inflation under free banking. In other words, free banking produce more stable inflation rates than central-banking regimes in four countries.

However, the other countries in the sample do not lend support to this conclusion. Further results show that the difference in the inflation variances under the two monetary regimes is significantly positive for two countries. This result implies that inflation under 
free banking is more volatile than inflation under central banking. In other words, centralbanking regimes produce more stable inflation rates than free-banking regimes in two countries. Finally, three countries show no significant difference exists in the inflation variances under the two monetary regimes.

Therefore, we cannot infer that central-banking regimes provide more stable inflation rates when compared to free-banking regimes.

Table B.1: Inflation Variances During the Free-Banking Era and After Central Banking Began.

\begin{tabular}{|c|c|c|c|c|}
\hline Country & $\begin{array}{c}\text { Inflation Variance } \\
\text { During Free Banking }\end{array}$ & $\begin{array}{c}\text { Inflation } \\
\text { Variance After } \\
\text { Central Banking } \\
\text { Began }\end{array}$ & $\begin{array}{l}\text { Change in } \\
\text { Inflation } \\
\text { Variance }\end{array}$ & F-test \\
\hline Australia & 33.16 & 25.39 & 7.77 & 1.31 \\
\hline Canada & 89.76 & 35.24 & 54.52 & $2.55^{\star *}$ \\
\hline France & 66.13 & 204.90 & -138.77 & $3.10^{* * *}$ \\
\hline Italy & 30.82 & 1628.15 & -1597.33 & $52.86^{* * *}$ \\
\hline New Zealand & 41.99 & 36.27 & 5.72 & 1.16 \\
\hline Spain & 80.81 & 61.13 & 19.68 & 1.32 \\
\hline Switzerland & 45.25 & 117.08 & -71.83 & $2.59^{* *}$ \\
\hline Sweden & 21.46 & 156.8 & -135.34 & $7.31^{* * *}$ \\
\hline United States & 125 & 79.74 & 45.26 & $1.57^{*}$ \\
\hline
\end{tabular}




\section{Appendix C}

In this appendix, I will check on the robustness of my results shown in Chapter 5 Table 5.2. The results in Table 5.2 illustrate the effect of having only a currency board, being only on the fast track to join the European Union, or having both characteristics on the level of inflation rates in transition economies. The estimated coefficients in front of each of the three dummy variables of interest carried a statistically significant negative sign, showing that restraining the discretionary power to set macro policies would lead to lower inflation rates. However, as I mentioned it in the chapter, the choice of the monetary regime in my regression is taken as exogenous. To address the possible simultaneity bias of my regression I need to control for certain economic preconditions that influence the choice of the monetary institutions. A good proxy appears to be the measure of per-capita GDP in the twenty-two transition countries under study.

To examine the determinants of inflation I estimate a regression that takes the following form:

$$
\text { Inflation }=f(\mathrm{CB}, \mathrm{EURO}, \mathrm{BOTH}, \mathrm{X})
$$

Where all the variables are the same as in the chapter but $\mathrm{X}$ includes, in addition to all previous variables, a measure of per-capita GDP. 
Table C.1: Determinants of the Inflation Rates for Transition Countries in 2001

\begin{tabular}{|l|c|}
\hline \multicolumn{1}{|c|}{ Independent Variables } \\
\hline Constant & $46.45^{\star * *}$ \\
Currency Board & $(3.00)$ \\
Fast Track to Join Euro & -14.61 \\
& $(1.74)$ \\
Both Currency Board \& Fast Track to Join Euro & $-17.88^{* *}$ \\
& $(2.90)$ \\
Budget Deficit (Share of GDP) & -13.13 \\
& $(1.27)$ \\
Trade Volume (Share of GDP) & 4.00 \\
& $(0.53)$ \\
GDP Growth & 0.00 \\
Per Capita GDP & $(0.87)$ \\
& $-2.88^{\star * *}$ \\
Independence of Central Bank & $(3.09)$ \\
& $0.00^{*}$ \\
Liberalization & $(1.95)$ \\
Regional Dummy & -4.15 \\
& $(0.36)$ \\
Gini Coefficient & $-9.08^{\star * *}$ \\
& $(2.90)$ \\
\hline R-Squared & $12.64^{*}$ \\
Number of Observation & $(1.87)$ \\
\hline
\end{tabular}

Notes: Absolute t-ratios in parenthesis

Significance levels are represented by: ${ }^{* * *} 1 \%,{ }^{* *} 5 \%,{ }^{*} 10 \%$

The results in Table C.1 show a lack of robustness in the results presented in the chapter 5 Table 5.3. The effect of having a currency board, or having both a currency board and being on the fast track to join the European Union carry a negative sign but are statistically insignificant.

The results could certainly be improved and more reliable if I could include a panel study for the year 1995-2002 across all transition countries. 


\section{References}

Aizenman, J. “Inflation, Tariffs and Tax Enforcement Costs," Journal of International Economic Integration v2, pp.12-28, 1987.

Alesina, A., and L. Summers. "Central Bank Independence and Macroeconomic Performance," Journal of Money, Credit, and Banking, pp.157-162,1993.

Altig, D. "Why Is Stable Money Such a Big Deal?" Federal Reserve Bank of Cleveland, Economic Commentary, May 1, 2002.

Banaian, K., R. Burdekin, and T. Willet. "On the Political Economy of Central Bank Independence.” In K. D. Hoover and Steven M. Sheffrin (eds), Monetarism and the Methodology of Economics. Great Britain: Edward Elgar Publishing, pp.178197, 1995.

Barro, R. "Inflation and Growth," Federal Reserve Bank of Saint Louis Review, 78, pp.153-169, 1996.

Barro, R. J., and D. B. Gordon. " Rules, Discretion, and Reputation in a Model of Monetary Policy," Journal of Monetary Economics, pp.101-121, 1983.

Bayoumi, T., and B. Eichengreen. 'Shocking Aspect of European Monetary Unification.' in B. Eichengreen (ed.), European Monetary Unification, Theory, Practice, and Analysis, Cambridge, London: The MIT Press, pp.73-109, 1993.

Bayoumi, T., and B. Eichengreen. 'Ever Closer to Heaven? An Optimum Currency Area Index for European Countries,' European Economic Review, 41, pp.761-770, 1997.

Bernanke, B.S., and A. S. Blinder. "The Federal Funds Rate and The Channels Of Monetary Transmission," American Economic Review, 82, pp. 901-921, 1992.

Bernanke, B.S., and I. Mihov. "Measuring Monetary Policy,” NBER WorkingPaper No. $5145,1995$.

Brainard W. "Uncertainty and the Effectiveness of Policy," American Economic Review, 57, pp.411-425, 1967.

Brunner K. (1985). "Monetary Policy and Monetary Order, In Monetary Policy and Monetary Regimes," Center for Research in Government Policy and Business, Number CS-17, Rochester N.Y.: Graduate School of Management, University of Rochester.

Bryan, M. "On the Origin and Evolution of the Word Inflation," Federal Reserve Bank of Cleveland, Economic Commentary, October 15, 1997. 
Caporale, T., and K. B., Grier. "A Political Model Of Monetary Policy With Application To The Real Fed Funds Rate," Journal of Law and Economics, 41, pp.409-428, 1998.

Camara, G., B. Craig and, C. Waller. "Dollarization via Currency Substitution," Unpublished Working Paper, Federal Reserve Bank of Cleveland, May 14, 2001.

Carlson, J. "Maintaining a Low Inflation Environment," Federal Reserve Bank of Cleveland, Economic Commentary, March 1, 1997.

Clarida, R., J. Gali and M. Gertler. "Monetary Policy Rule in Practice: Some International Evidence," European Economic Review, 42, pp.1033-1067, 1997.

Clarida, R., J. Gali and M. Gertler. "Monetary Policy Rules and Macroeconomic Stability: Evidence and Some Theory," Quarterly Journal of Economics, 115, pp.147-180, 2000.

Craig, B. "Competing Currencies: Back to the Future?" Federal Reserve Bank of Cleveland, Economic Commentary, October 15, 1996.

Cukierman, A. Central Bank Strategy, Credibility, and Independence: Theory and Evidence. Cambridge, Mass.: MIT Press, 1992.

Cukierman, A., G. Miller, and B. Neyapti. "Central Bank Reform, Liberalization and Inflation in Transition Economies- An International Perspective,"Center for Economic Research Paper No.2000-106, 2000.

De Grauwe, P. Economics of Monetary Union, Oxford University Press, Oxford, 2000.

Deininger, K.and L. Squire. "A new data set measuring income inequality," World Bank Economic Review, 10(3), September, pp.565-91, 1996.

Dowd, K. "Is Banking a Natural Monopoly?” Kyklos 45(3), pp. 379-92, 1992.

Dowd, K. “Australian Free Banking," In Kevin Dowd (ed.), The Experience of Free Banking, London, Routledge, pp.48-78, 1992.

Dowd, K. Laissez-Faire Banking. London, Routledge, 1993.

Dowd, K. “Automatic Stabilizing Mechanisms under Free Banking," Cato Journal 7, pp.643-659, 1988.

Dowd, K. “Australian Free Banking," In Kevin Dowd (ed.), The Experience of Free Banking, London, Routledge, 1992, 48-78. 
Duisenberg, W. "Economic and Monetary Union in Europe-The Challenges Ahead," In New Challenges For Monetary Policy, Federal Reserve Bank of Kansas City, 1999.

Ellison M., and N. Valla. "Learning, Uncertainty and Central Bank Activism in an Economy With Strategic Interactions," European Central Bank, Working Paper, No 28, 2000.

Eichengreen B. (1992). "Is Europe an Optimum Currency Area?" In H. Grubel and S. Borner (eds), The European Community after 1992: Perspectives from the Outside, Basingtoke, England: Macmillian, pp. 138-61.

England, C. "The Future of Currency Competition," In James, Dorn (ed), The Future of Money in the Information Age. Washington, D.C.: The Cato Institute, 1997.

Faust, J., J.H. Rogers and J.H. Wright. "An Empirical Comparison of Bundesbank and ECB Monetary Policy Rules," Federal Reserve Board International Finance Discussion Papers, No.705, 2001.

Feldstein M. "The Political Economy of the European Economic and Monetary Union: Political Sources of an Economic Liability," The Journal of Economic Perspectives, 11, pp.23-42, 1997.

Feldstein, M. "The European Central Bank and the Euro: The First Year," Journal of Policy Modeling, 22, pp.345-354, 2000.

Fisher, S. “ The Role of Macroeconomic Factors in Growth,"NBER Working Paper No4565, 1993.

Frankel, J., and A. Rose."The Endogeneity of the Optimum Currency Area Criteria." The Economic Journal, pp.1009-25, 1998.

Fratianni, M., and J. von Hagen. “European Monetary Union and Central Bank Independence," Regional Science and Urban Economics, pp.401-425, 1993.

Friedman, D. and K. Macintosh. "Technology and the Case for Free Banking," In Klein and Foldvary (eds), Technological Advancement and the Changing Context of Public Policy Justification, 2001.

Friedman, M. A Program for Monetary Stability. New York: Fordham University Press, 1960.

Friedman, M. The Optimum Quantity of Money and Other Essays. Chicago: Aldine Publishing Company, 1969. 
Friedman, M. "Monetary Policy: Theory and Practice," Journal of Money, Credit, and Banking v14, pp.98-118, 1982.

Friedman, M. “The Lag In Effect Of Monetary Policy,” Journal Of Political Economy, 69, pp.447-466, 1961.

Friedman, M. "The Role Of Monetary Policy,” American Economic Review,pp.1- 17, 1968.

Greenspan, A. "Fostering Financial Innovation: The Role of Government," In James Dorn (ed), The Future of Money in the Information Age. Washington, D.C.: The Cato Institute, 1997.

Gwartney, J. and Lawson R. Economic Freedom of the World. Annual Report 2001. The Fraser Institute, 2001.

Ghosh, A., A. M. Gulde, and H. Wolf. "Currency Boards: The Ultimate Fix?” Work Paper of the International Monetary Fund No98/8, 1998.

Ghosh, A., A.M. Gulde, and H. Wolf. "Currency Boards: More Than a Quick Fix," Economic Policy v31, pp.271-335, 2000.

Grier, K. B. "The Political Economy of Monetary Policy," Ph.D. diss., Washington University, St. Louis, 1984.

Grier, K. B. "On the Existence of a Monetary Cycle," American Journal ofPolitical Science, 33, pp. 376-389, 1989.

Hafer R.W., and A.M. Kutan "Detrending and Money-Output Link," Southern Economic Journal, 69, pp.159-174, 2002.

Hafer, R.W., and D.C. Wheelock "The Rise and Fall of a Policy Rule: Monetarism at the St. Louis Fed, 1968-1986,"The Federal Reserve Bank of St. Louis Review, 83, pp.1-31, 2001.

Hayek, F. Denationalization of money, London: Institute of Economic Affairs, 1976.

Hayek, F. Choice in Currency: A Way to Stop Inflation, London: Institute of Economic Affairs, 1976.

Hanke, S., and K. Schuler. "Currency Convertibility: A Self-Help Blueprint for the Commonwealth of Independent States," Cato Foreign Policy Briefing Paper No. 17, 1992 
Hanke, S., and K. Schuler. Financial Reform and Economic Development: The Currency Board System for Eastern Europe, in Boettke (ed.) The Collapse of Development Planning, New York and London, New York University Press, 1994.

Hanke, S. "Currency Boards," Annals of the American Academy of Political and Social Science v579, pp.87-105, 2002

Hanke, S. "The Disregard for Currency Boards Realities," The Cato Journal v20, pp 4959,2000

Issing, O. “ The ECB's Monetary Policy: Experience After the First Year," Journal of Policy Modeling, pp.325-343, 2000.

Kydland, F. E., and E. C. Prescott. " Rules Rather than Discretion: The Inconsistency of Optimal Plans," Journal of Political Economy, pp.473-491, 1977.

Klein, B. “ The Competitive Supply of Money”, Journal of Money Credit and Banking 6, pp.423-454, 1974.

Martin-Das, J. The European Monetary Union in a Public Choice Perspective: A Political-Economic Approach to the Implications of Macroeconomic Shocks. Edward Elgar Pub, 2002.

McCallum, Bennett. Monetary Economics: Theory and Policy, New York: Macmillan, 1989.

Meltzer, A. H. "Limits of Short-run Stabilization Policy: Presidential Address to the Western Economic Association, July 1986," Economic Inquiry, 25, pp.1-14, 1987.

Meltzer, A. H. "Money and Monetary Policy: An Essay in Honor of Darryl Francis," Federal Reserve Bank of Saint Louis Review, 83,pp.23-31, 2001.

Mitchell, B. International Historical Statistics, New York: Stockton Press; London: Macmillan, 1993.

Mundell, R. “A Theory of Optimum Currency Areas,” American Economic Review, 51, 1961.

Motley, Brian. "Growth and Inflation: A Cross-Country Study," Federal Reserve Bank of San Francisco Economic Review v0, pp. 15-28,1998.

Nataf, P. "Free Banking in France," In Kevin Dowd (ed.), The Experience of Free Banking, London, Routledge, pp.123-137, 1992. 
Nenovsky, N. "Comparing Currency Board Automatic Mechanism in Bulgaria,Estonia and Lithuania," Journal des Economistes et de Etudes Humaines v11, pp.575$615,2001$.

Orphanides, A."Monetary Policy Evaluation with Noisy Information," Federal Reserve Board Finance and Economics Discussion Series No.50, 1998.

Orphanides, A. "The Quest For Prosperity Without Inflation," European Central Bank Working Paper, No. 15, 2000.

Orphanides, A. "Monetary Policy Rules and the Great Inflation," American Economic Review, 92, pp.115-120, 2002.

Phelps, E. "Money Wage Dynamics and Labor Market Equilibrium,"Journal of Political Economy, 76, pp. 678-711, 1968.

Persson, T., and G. Tabellini, Macroeconomic Policy, Credibility, and Politics, London, Harwood Academic Publishers, 1990.

Pesek, B. and T. Saving. Money, Wealth and Economic Theory. New York: Macmillan, 1967.

Rasche, R.H., D.L. Thornton. “The Monetary/Fiscal Policy Debate: A Controlled Experiment," Monetary Trends, Federal Reserve Bank of St. Louis, 2001.

Rogoff, K. “ The Optimal Commitment to an Intermediate Monetary Target." Quarterly Journal of Economics, pp.1169-1189, 1985.

Rose, A. "One Money, One Market: Estimating the Effect of Common Currencies on Trade." Economic Policy: A European Forum, pp. 7-33, 2000.

Rose A., and E. van Wincoop. "National Money as a Barrier to International Trade: The Real Case for Currency Union.” American Economic Review, pp.386-90, 2001.

Roubini, N. "The Case Against Currency Boards: Debunking 10 Myths about the Benefits of Currency Boards," On line at http://pages.stern.nyu.edu/ nroubini/asia/CurrencyBoardsRoubini.html,1998.

Sachs, J. An overview of Stabilization Issues Facing Economies in Woo, Parker, and Sachs (eds.) Transition in Economies in Transition, Cambridge Massachusetts MIT press, 2001.

Salvatore, D. "The Euro, The European Central Bank, and the International Monetary System," The Annals Of The American Academy of Political and Social Science, pp. 153-167, 2002. 
Schuler, K. "The World History of Free Banking: An overview," In Kevin Dowd (ed.), The Experience of Free Banking, London, Routledge, pp.17-47, 1992.

Schuler, K. Should Developing Countries Have Central Banks? Currency Quality and Monetary Systems in 155 Countries, London, The Institute of Economics Affairs, 1996.

Sechrest, L. Free Banking. Theory, History, and a Laissez Faire Model, Westport, CT, Quorum Books, Greenwood Publishing, 1993.

Selgin, G. The Theory of Free Banking. Money Supply under Competitive Note Issue, Totowa, NJ, The Cato Institute, Rowman \& Littlefield Publisher, 1988.

Selgin, G. and L. White. " How Would the Invisible Hand Handle Money?"Journal of Economic Literature 32, pp1718-49, 1994.

Shughart, W., and R. Tollison. " Preliminary Evidence on the Use of Inputs by the Federal Reserve System,” American Economic Review v73, pp. 291-304, 1983.

Sims, C. A. "Money, Income and Causality," American Economic Review, 62, pp. 540$542,1972$.

Sims C. A. "Interpreting the Macroeconomic Time Series Facts: The Effects of Monetary Policy,"European Economic Review, 36, pp. 975-1011, 1992.

Stevens, E. “The Euro.” Economic Commentary, Federal Reserve Bank of Cleveland, 1999.

Stevens, E. "Electronic Money and the Future of Central Banks," Federal Reserve Bank of Cleveland, Economic Commentary, March 1, 2002.

Toma, M. "Inflationary Bias of the Federal Reserve System: A Bureaucratic Perspective," Journal of Monetary Economics v10, pp.163-90, 1982.

Toma, Mark. Monetary Policy in Shughart, Razzolini (eds.) The Elgar Companion to Public Choice, Cheltenham, U.K. and Northampton, Mass., 2001.

Tullock, G. “Competing Monies,” Journal of Money, Credit and Banking 7, pp.491-97, 1975.

Vaubel, R. “ Currency Competition versus Governmental Money Monopolies," Cato Journal 5, pp.927-942, 1986.

Vaubel, R. "Currency Competition and European Monetary Integration," The Economic Journal 100, pp.936-946, 1990. 
Weber, E. “Currency Competition in Switzerland, 1826-1950,"Kyklos, 41(3), pp. 459-78, 1988.

Weber, E. "Free Banking in Switzerland After the Liberal Revolutions in the $19^{\text {th }}$ Century," In Kevin Dowd (ed.), The Experience of Free Banking, London, Routledge, pp.187-205, 1992.

White, L. “Free Banking in Scotland before 1844," In Kevin Dowd (ed.), The Experience of Free Banking, London, Routledge, pp.157-186, 1992

Williamson, S. "Private Money and Counterfeiting," Economic Quarterly 88, pp.37-58, 2002. 